تأثير رزيمهاى متفاوت آبيارى بر ويزّى هاى فيزيولوزيك، عملكرد و بهرهورى آب زنوتيبهاى سيبزمينى (Solanum tuberosum L.) در اردبيل

آتوسا شفارودى'، عبدالقيوم قلى يورى “، محسن زواره"، داوود حسنيناه و برومند صلاحى

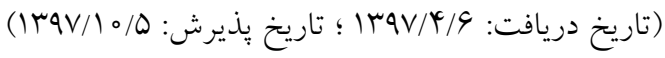

جكيده

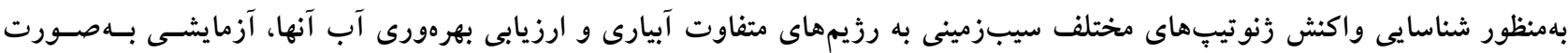

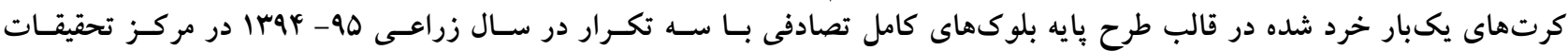

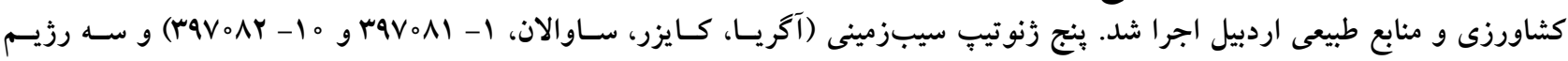

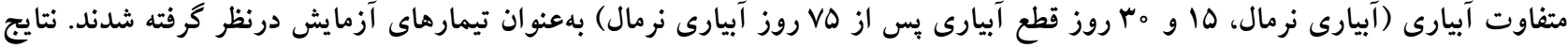

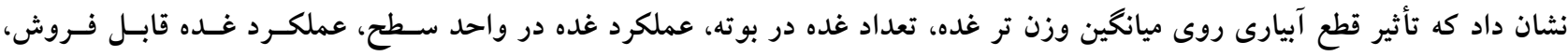

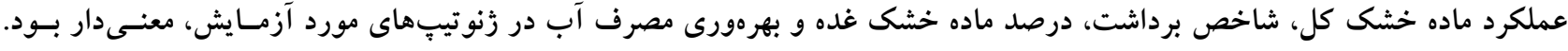

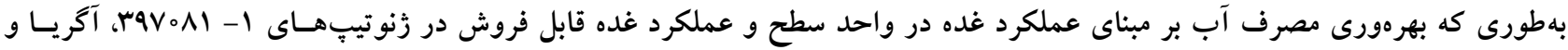

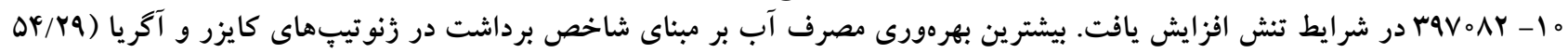

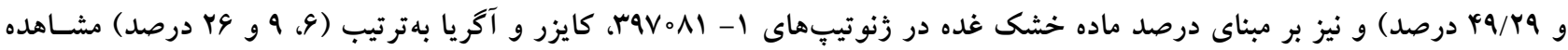

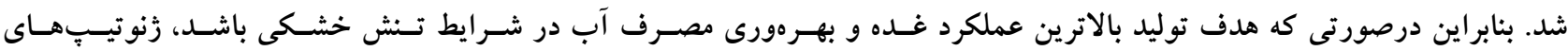

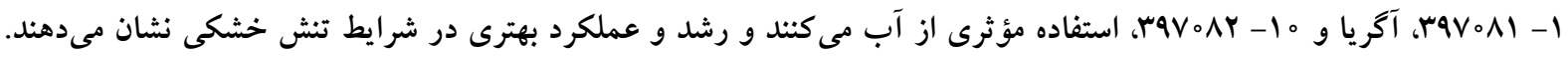

وازههاى كليدى: استفاده مؤثر از آب (EUW)، شاخص برداشت، كمآبيارى، عملكرد غده، عملكرد ماده خشك

او r. بهترتيب دانشجوى دكترى و دانشيار، كروه زراعت و اصلاح نباتات دانشكده كثاورزى، دانشكاه محقق اردبيلى

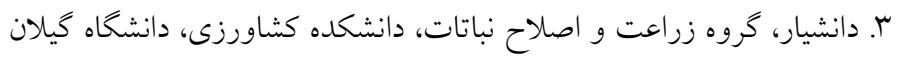

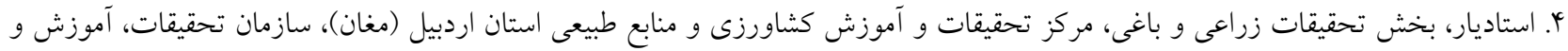
ترويج كثاورزى، اردبيل، ايران

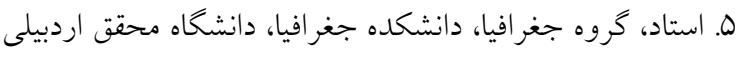

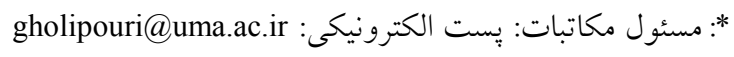


ريشهها مىتواند دو نتيجه نامطلوب را در بيى داشـته باشـد. اول

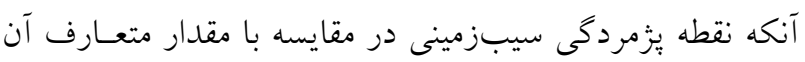

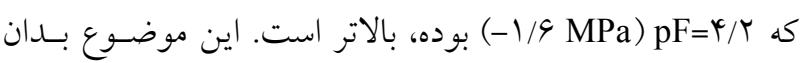

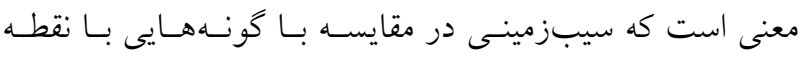

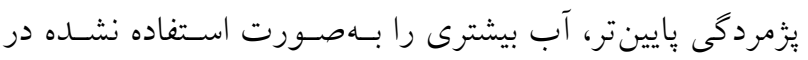

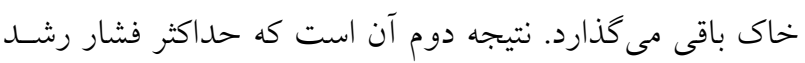

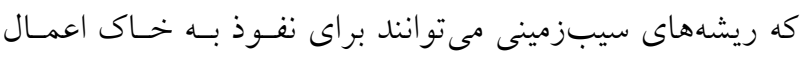

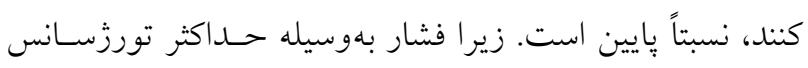

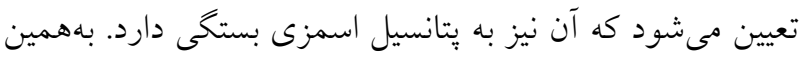

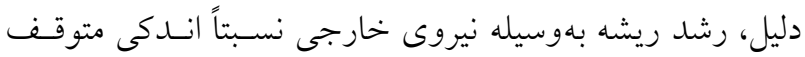

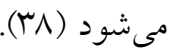
ضرورت استفاده و تخصيص بهينه آب و مطالعه دقيقتـر نقـش

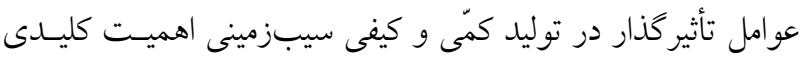

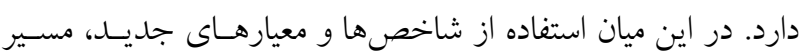

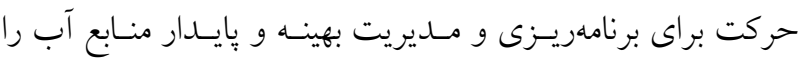

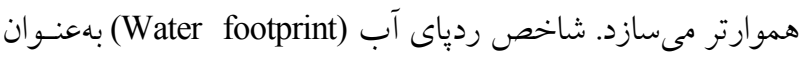

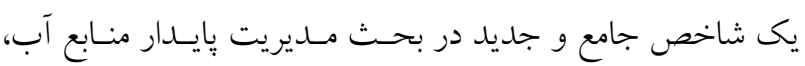

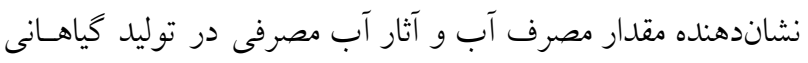
جون سيبزمينى است كه توسط هواكسترا (TV) معرفى شده است.

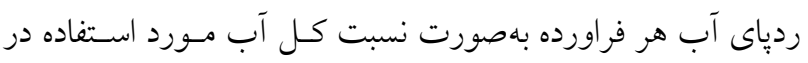
سطح مزرعه (مترمكعب) بهميزان توليد همان فراورده (تن) محاسبه مىشود كه نشـاندهنــده مقــار آب مصـرفى در توليـــ كياهـان مختلف است (YV). يافتهاى يك يزّوهش در اردبيـل نشـان داد

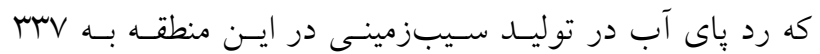

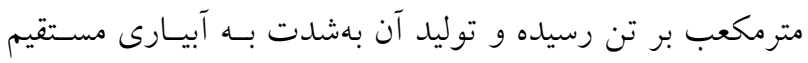

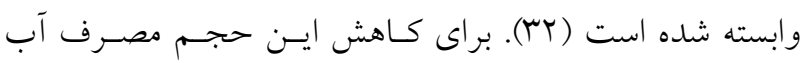

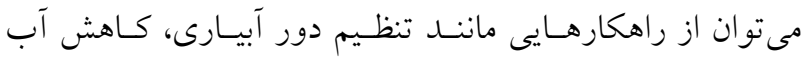

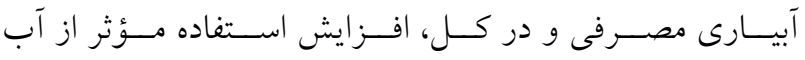
در مقايسه با بهـرمورى مصـرف (Effective use of water) (EUW)

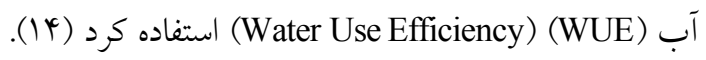

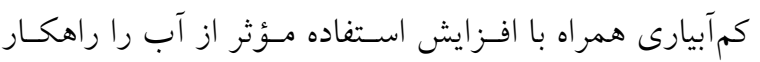

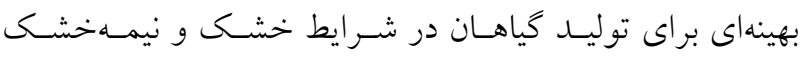

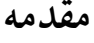

ايـران در يكسى از خشـكتـرين منـاطق جهـان واقـع شــده و در

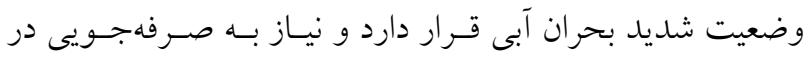

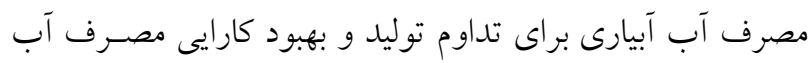

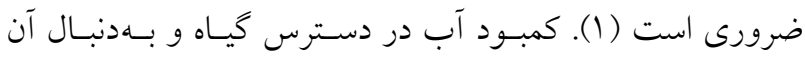

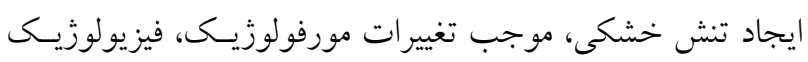

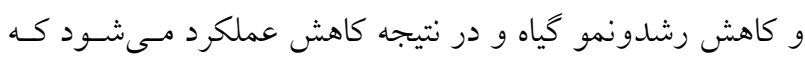

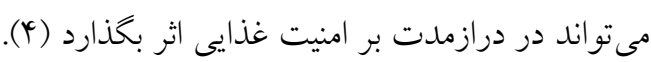

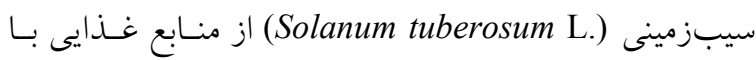

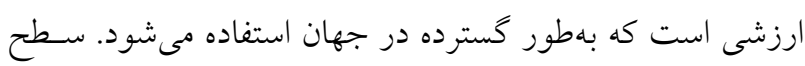

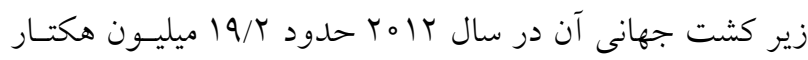

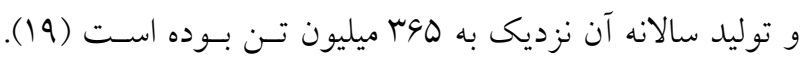

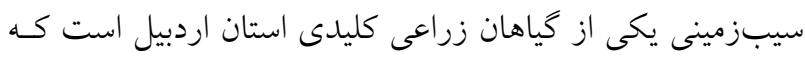

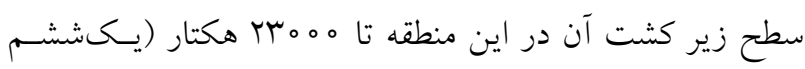

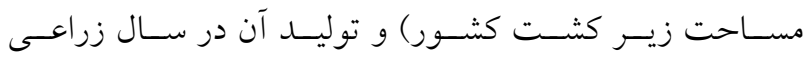
(Y)

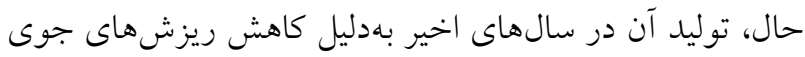
و كاهش دسترسى به منابع آب، كم شده است (YY) سيبزمينى بهواسطه سيستم ريشهاى نسبتاً كمعمق، كمتراكم

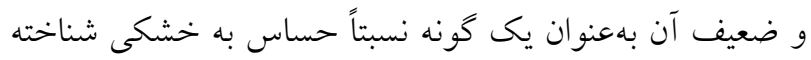

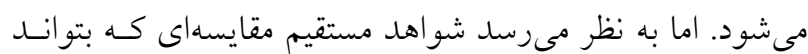

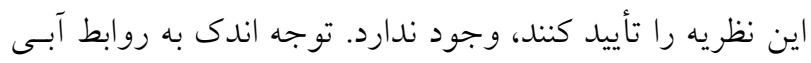

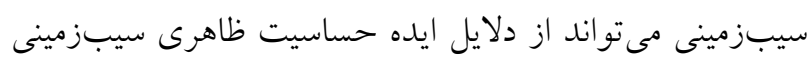

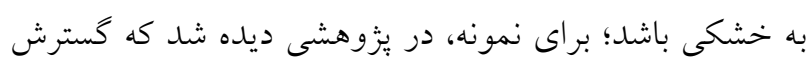

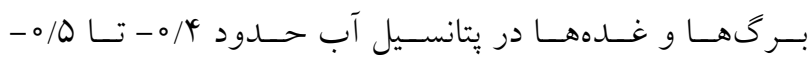

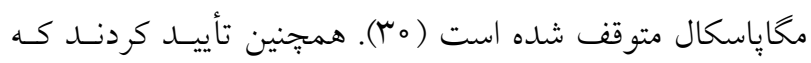

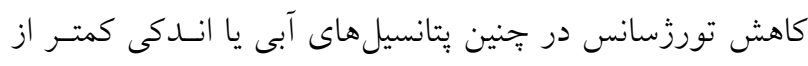

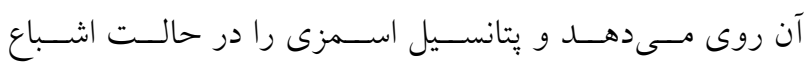

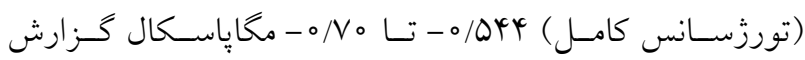

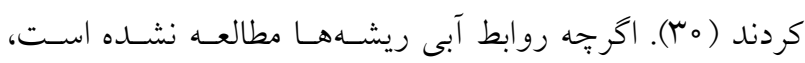

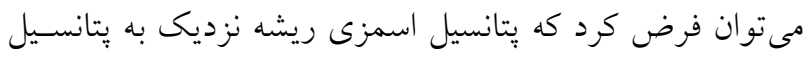

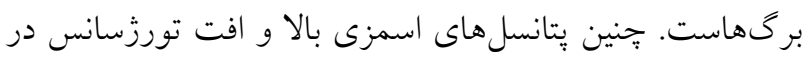




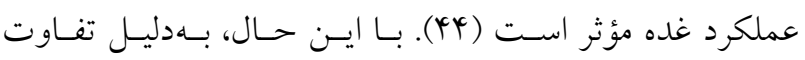

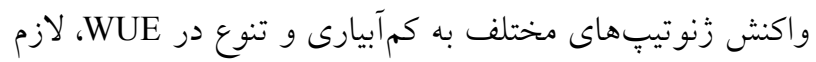

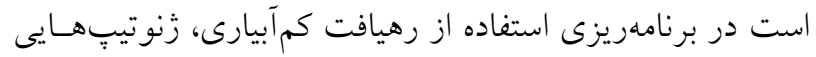
كزينش شوند كه بهترين واكنش را به كمآبيارى داشته و در كنار

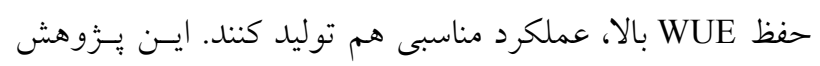

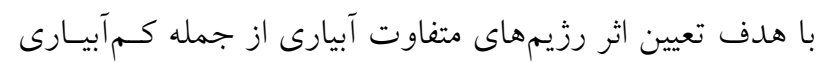

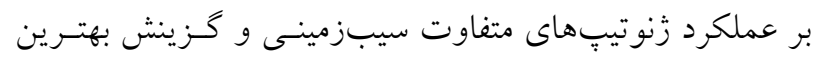

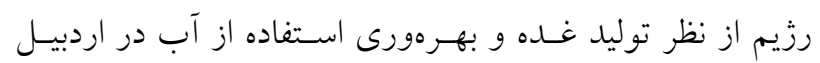

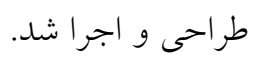

\section{مواد و روشها}

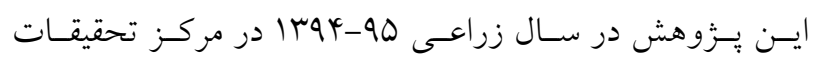

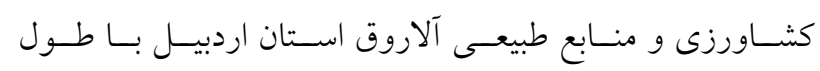

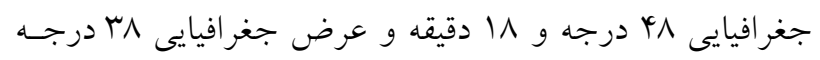

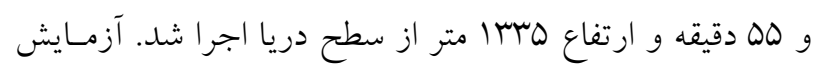

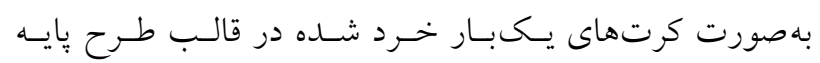

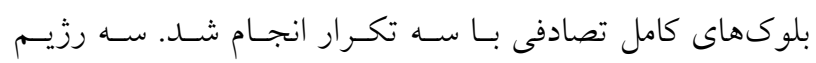

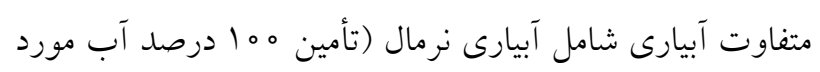

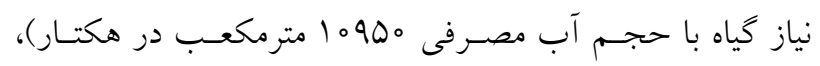

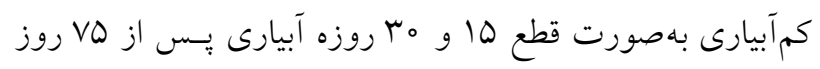

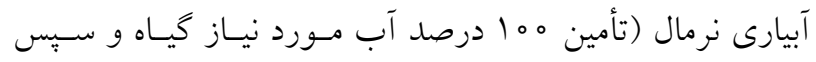

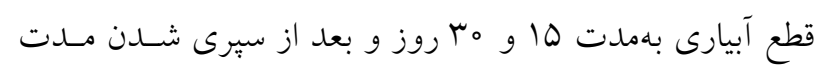

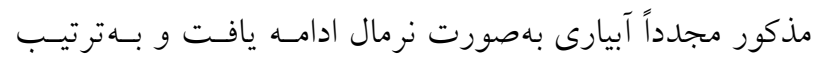

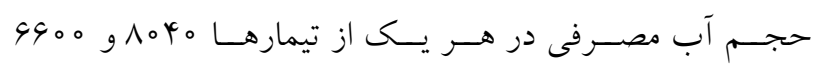

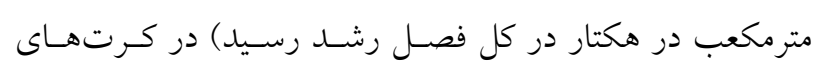

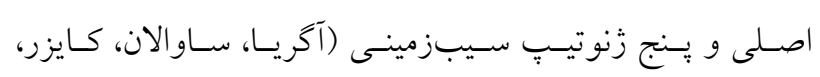

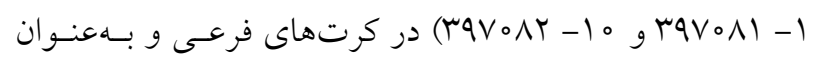

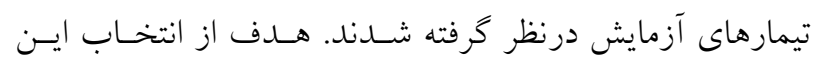

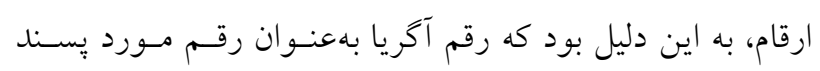

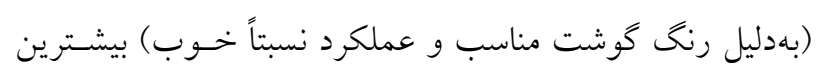

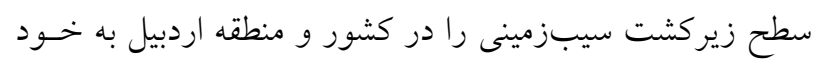

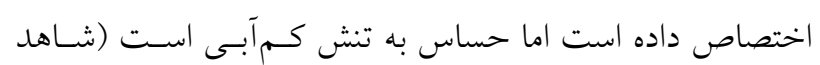

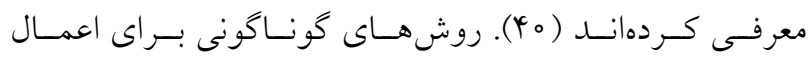

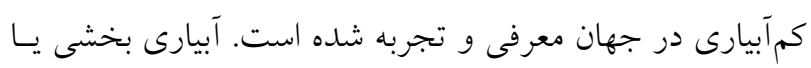

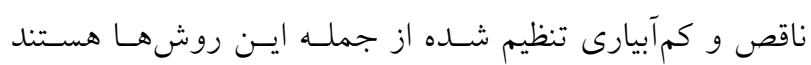

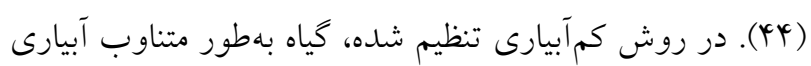
مىشود. تكرار اين تناوب تغييراتى در ساختار فيزيولوزيكى كياه

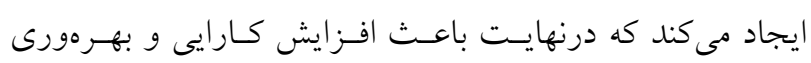
مصرف آب در كياه مىشود (1). در آزمايشى درباره تأثير تسنش كمآبى بر شش زنوتيب سيبزمينى مشخص شد كه زنوتيبهای

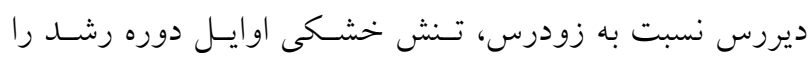
بهتر تحمل مى كنند (Y). با اين حال باسيو (11) در بررسى تسأثير

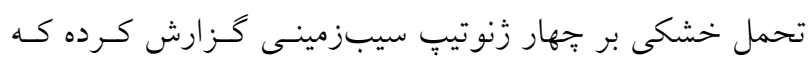

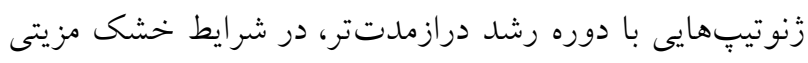

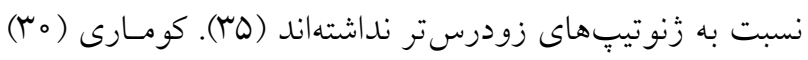

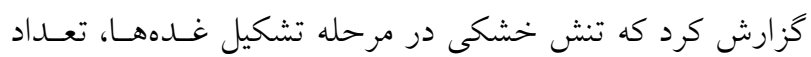

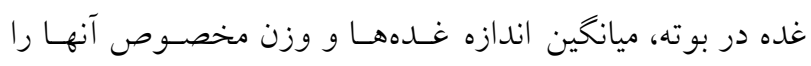

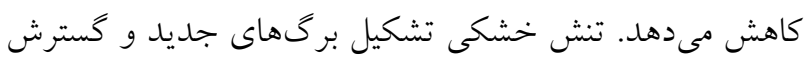

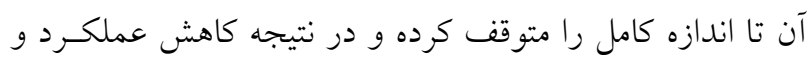

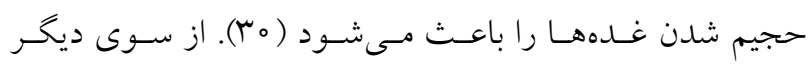

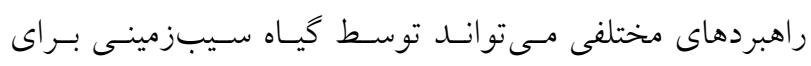
ساز كارى با شرايط تنش خشكى اتخاذ شود. بهطور مثال تعـداد غده كمتر مىتواند موجب برقرارى تعادل در توزيع مواد يروردهـ

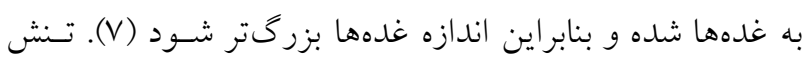

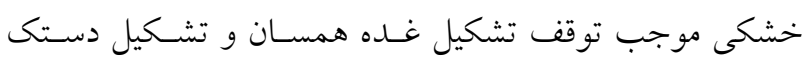

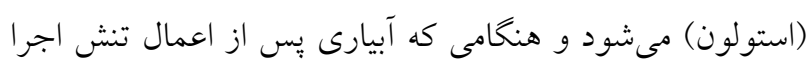

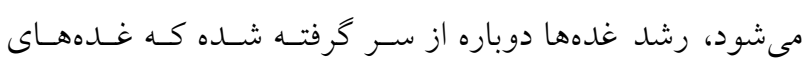

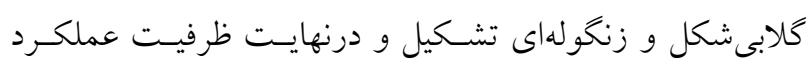

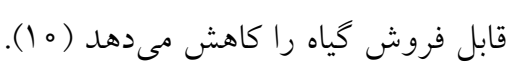

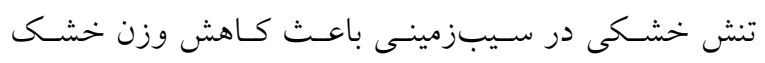

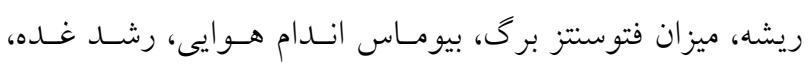

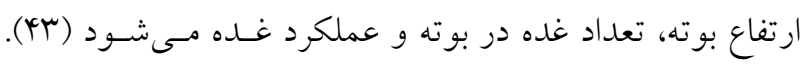

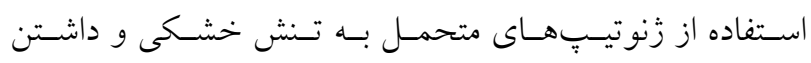

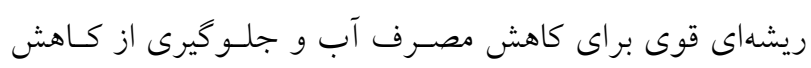


جدول ا. ويزّكىهاى فيزيكى و شيميايى نمونه مركب خاك مزرعه آزمايش

\begin{tabular}{|c|c|c|c|c|c|c|c|c|c|}
\hline ظرفيت تبادل & اسيديته & هدايت الكتريكى & قابل جذفر & قِابل جذيم & نيتروزن كل & ماده آلى & شن & سيلت & رس \\
\hline$(\mathrm{Cmolc} / \mathrm{kg})$ & & $(\mathrm{dS} / \mathrm{m})$ & \multicolumn{2}{|c|}{$(\mathrm{mg} / \mathrm{kg})$} & \multicolumn{5}{|c|}{ (درصد) } \\
\hline$T Y / T \Delta$ & $\mathrm{V} / \mathrm{\Lambda}$ & $\psi / \psi \wedge$ & YI & MN & $0 / r$ & $1 / \wedge 9$ & 49 & $\mu_{0}$ & $r r$ \\
\hline
\end{tabular}

آب از كرتهاى مجـاور بـهـ يكـديخر، بـين كـرتهـاى فرعى

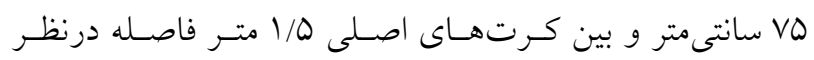

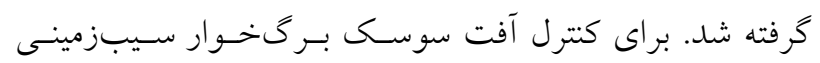
(سوسك كلرادو (Leptinotarsa decemlineata) كنفيدور بهميزان مOD ميلىليتر در هكتار استفاده شد. مبـارزه بـا علفهاى هرز بيش از غدهزايى و در دو نوبت بهصورت وجين

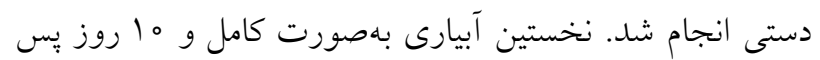

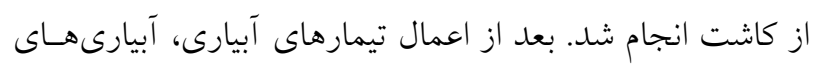

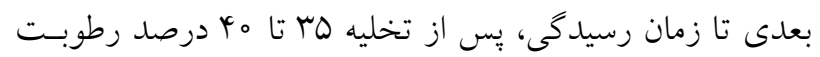

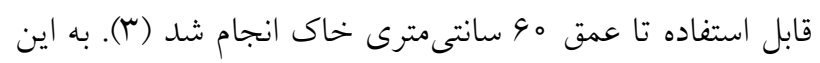

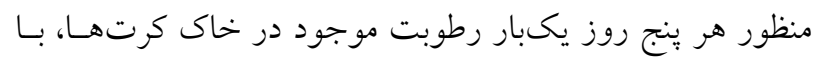

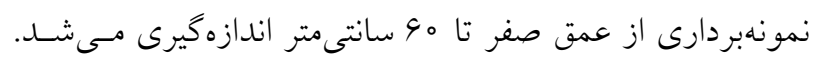

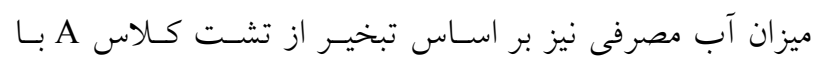

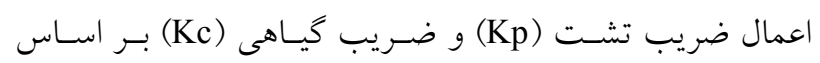

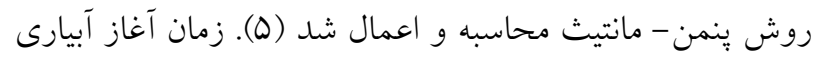

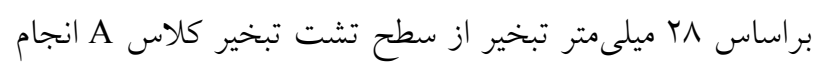

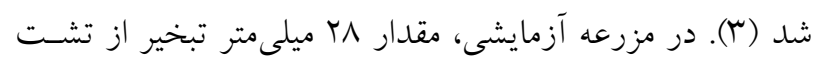

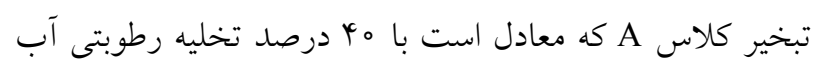

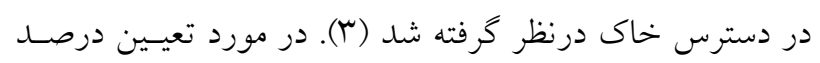

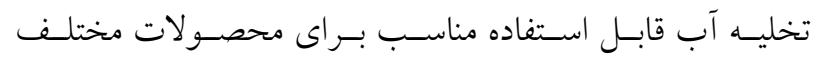

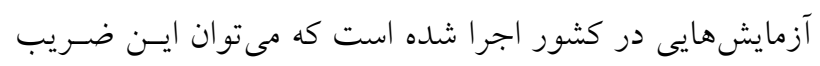

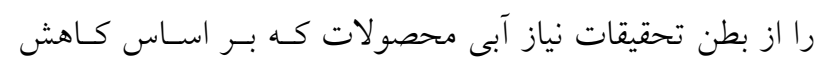

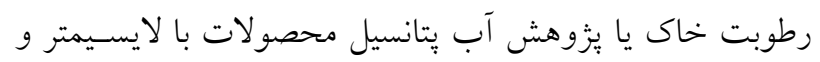

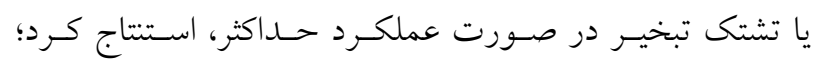

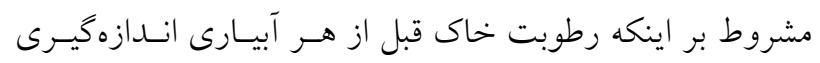

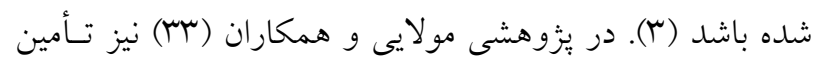
رطوبت خاك بر اساس ميزان تخليسه رطـوبتى از عمـق توسـعه

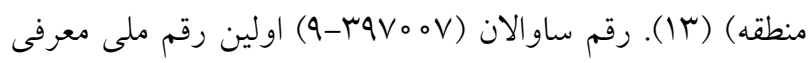

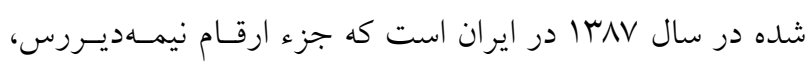

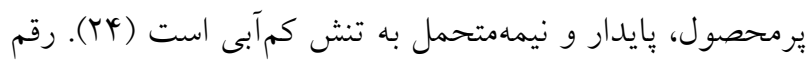

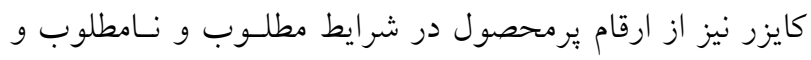

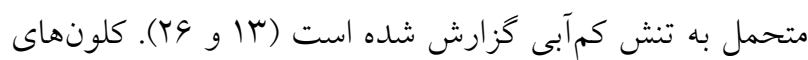
م

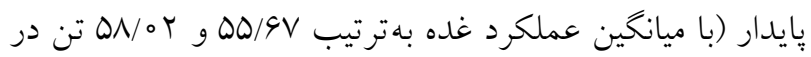

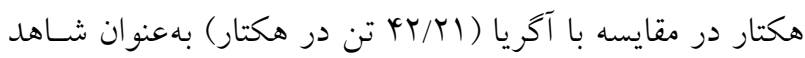

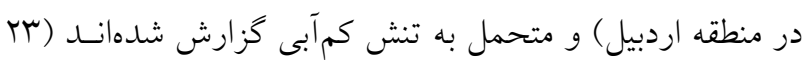

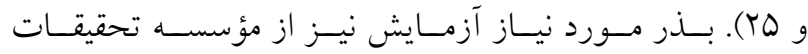
محصولات زراعى كشور ايرلند و ايستاه تحقيقات كشاورزى و منابع طبيعى اردبيل تهيه شد.

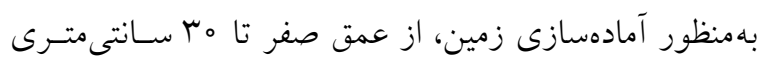

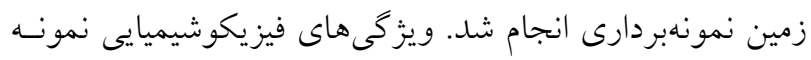

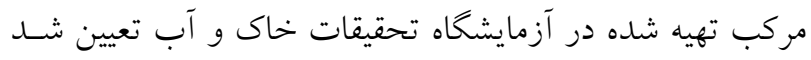

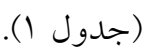

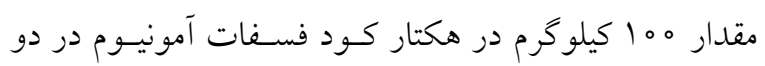

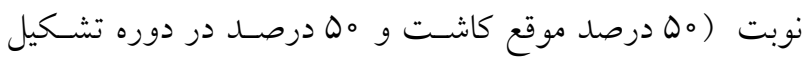

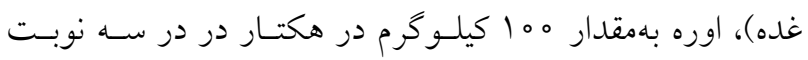

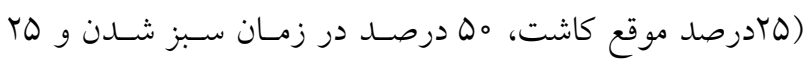

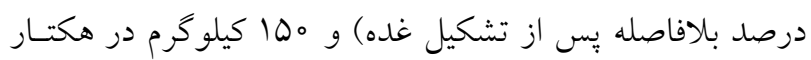

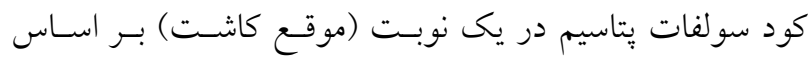

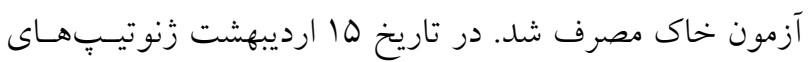

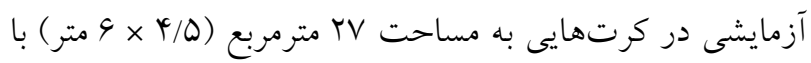

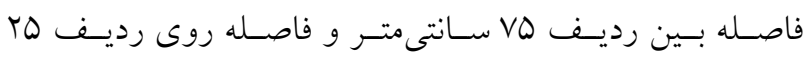

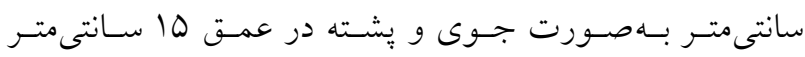
بلهورت دستى كشت شدند. براى جلو گيرى از حركت و نفـوذ 
جهـانى توصسيه شــه اسـت، بنـابر اين بـهــار گيرى ايسن روش

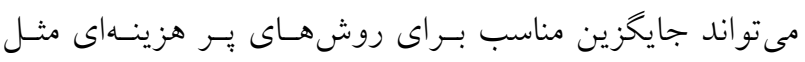

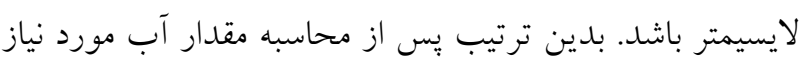

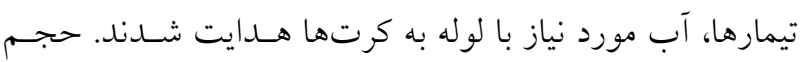

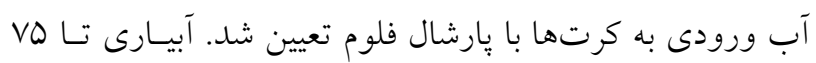
روز پِ از كشت در تمام تيمارها بهصورت نرمال انجام گرفت

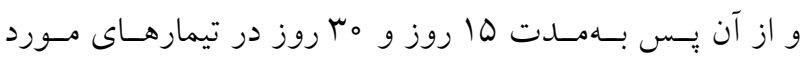
آزمايش آب قطع شد. بِ از قطع آبيـارى در تيمارهـاى مـورد

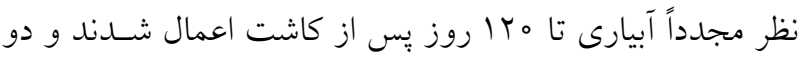

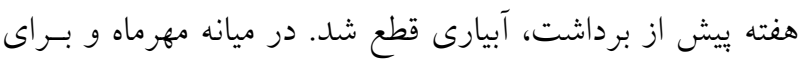
تعيين عملكرد غده، همه غدههاى موجـود در سططحى برابـر بـا

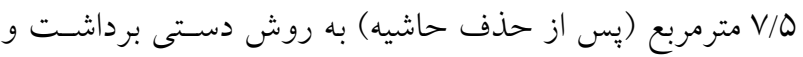

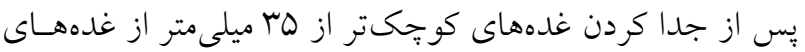

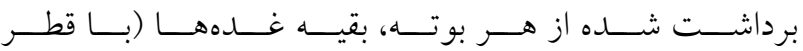
ه广 تا هQ - غدههاى بذرى-و بيش از هD ميلىمتر) توزين و علدد

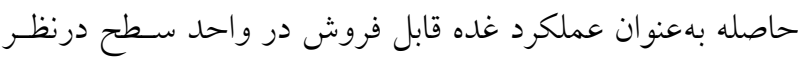

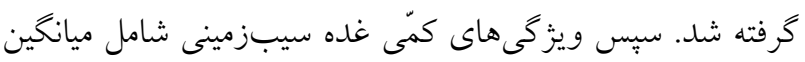

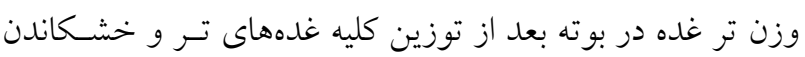

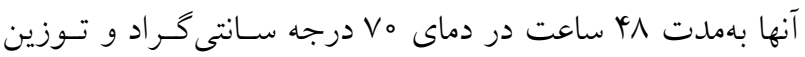

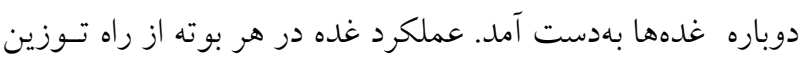
غدههاى تر هر بوته و غدههاى خشك هر بوته تعيين شـــ. بـراى محاسبه شاخص برداشت از رابطه زير استفاده شد (YN):

\section{$\mathrm{HI}=\mathrm{GY} / \mathrm{BY} \times 1 \circ \circ$}

كه در آن HI:شاخص برداشـت (درصـد)، GY: عملكــــ اقتصـادى

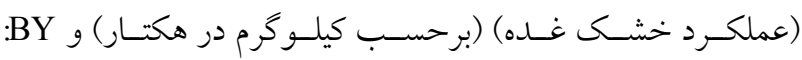

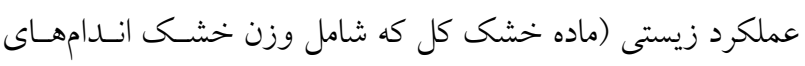

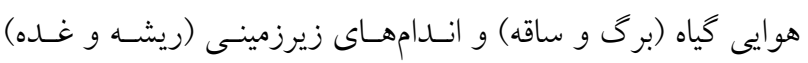

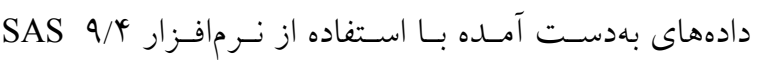

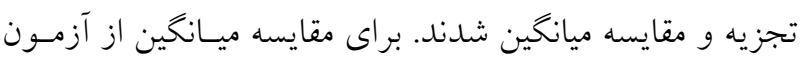

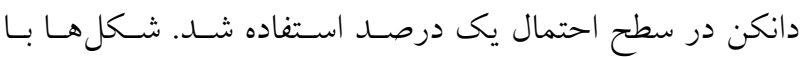

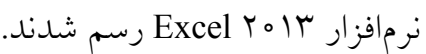

ريشه را مد نظر قرار دادنـــ. در ايسن بررسى زمـان آبيـارى بـر

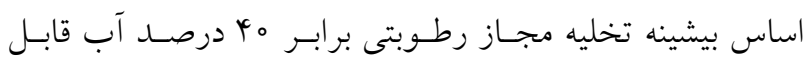

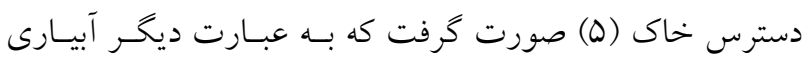

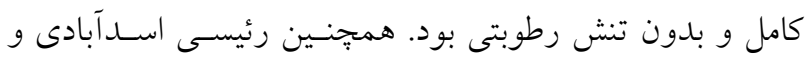

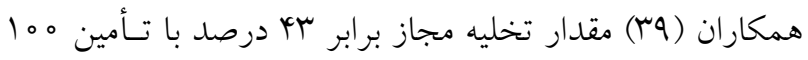

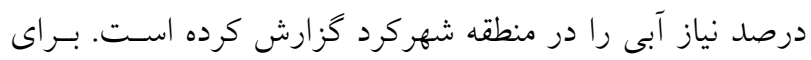
محاسبه مقدار آب مورد نياز كرتهاى آزمايشىى، از رابطـهـ زيــر

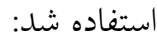

\section{$\mathrm{W}=\mathrm{A} \times \mathrm{Kc} \times \mathrm{Ep} \times \mathrm{Kp}$}

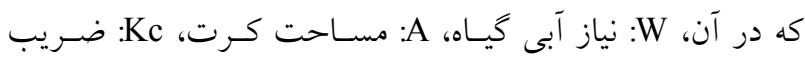

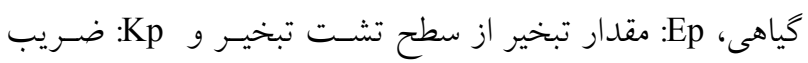

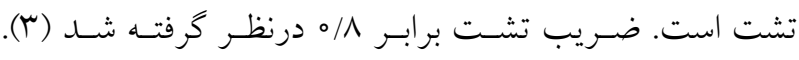
ضريب تشت بستكى به وضعيت استقرار تشت و محيط اطـراف

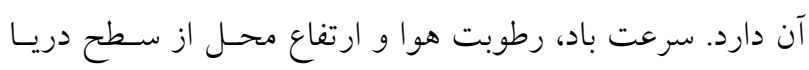
نيز بر ضريب تشت مؤثرند. در انتخاب ضريب مناسب تشت، نه

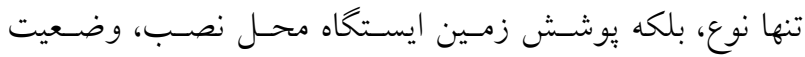
ييرامون تشت و همجنين شرايط كلى باد و رطوبت هوا نيز بايسـ درنظر كرفته شود (ضريب تشت كلاس A Aــه اسـتناد از نشـريه

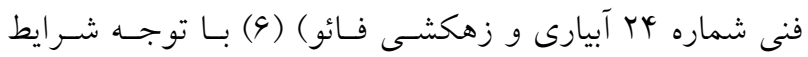

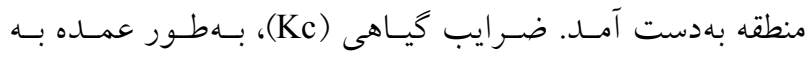
ويزگى هاى كياه و بهطور محدودتر به اقليم بستخى دارد. ضريب

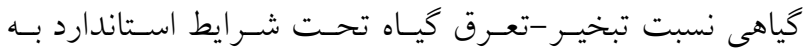
تبخير - تعرق كياه مرجع بوده و بسته به دوره رشد كياه به جهار

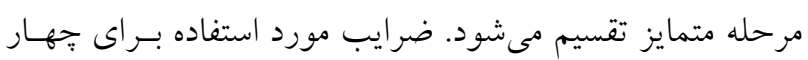

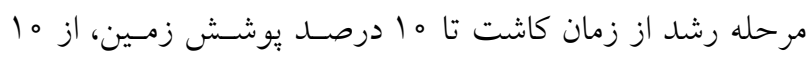

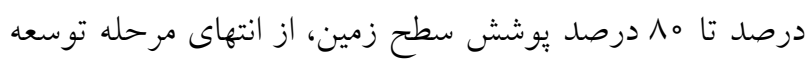

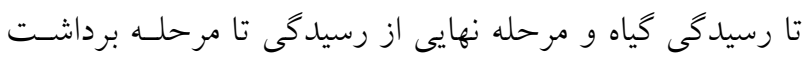

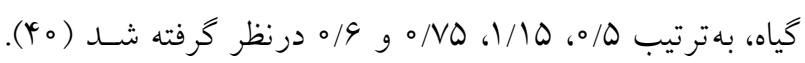

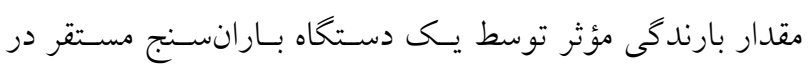

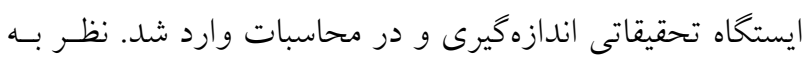

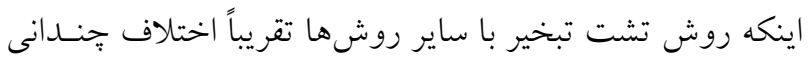

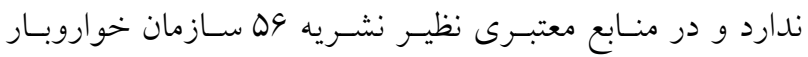




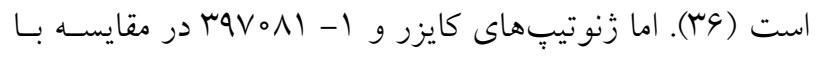

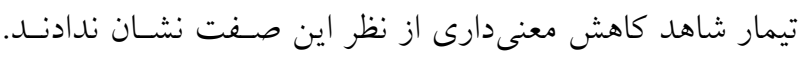

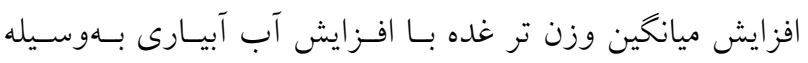

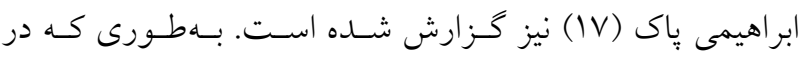

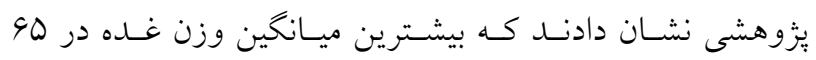

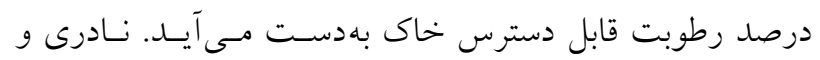

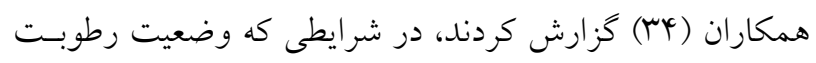
مطلوب خاك در مرحله رسيدكى بوته سيبزمينى وجود داشـته درانه

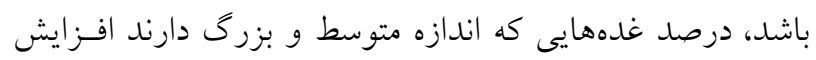

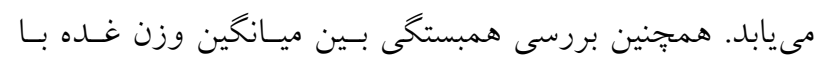

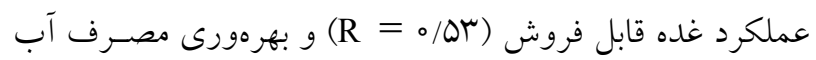

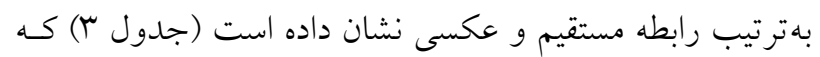

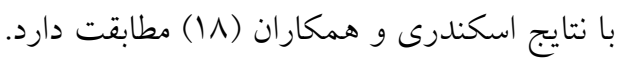

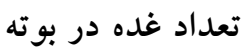

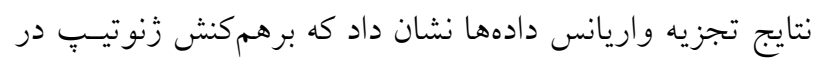

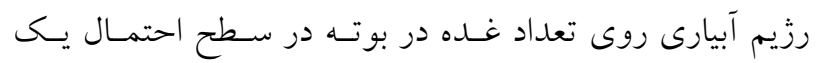

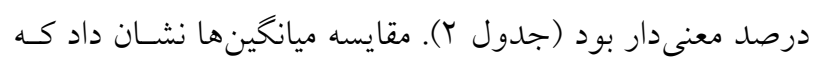

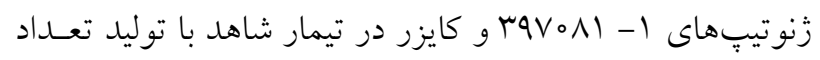

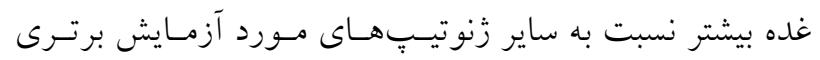

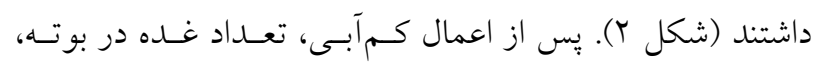

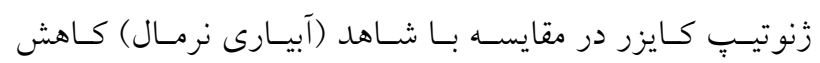

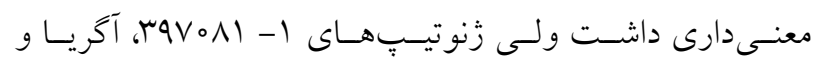

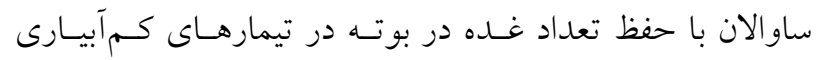
نسبت به تيمار شاهد تفاوت معنى دارى نشان ندادند (شـكل بان). زنوتيِهاى مختلـف از لحساظ تعـداد سـاقه در بوتـه و تعــاد غدههاى توليدى بهازاى هر ساقه تفــاوت زيـادى دارنـــ (V). از

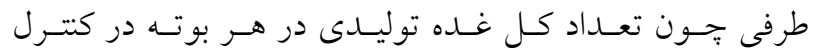

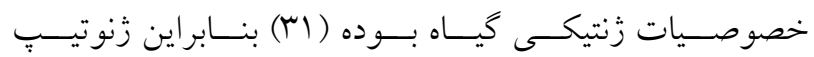

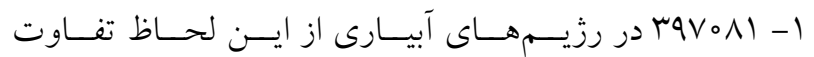

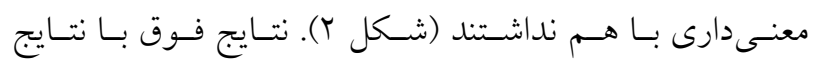

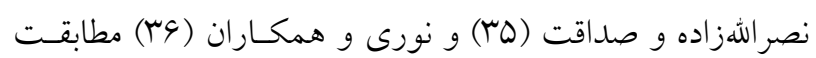

نتايج و بحث ميانخين وزن تر غده (كرم)

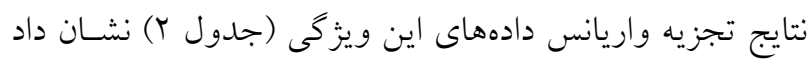

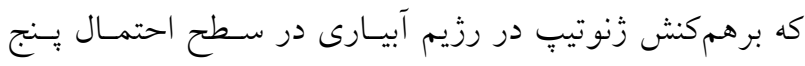

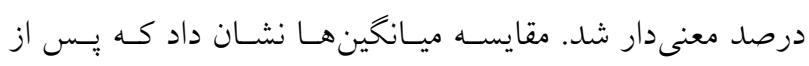

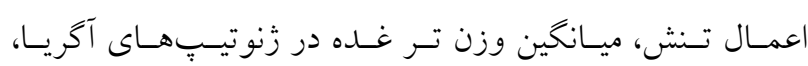

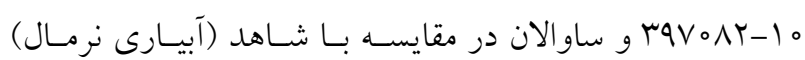

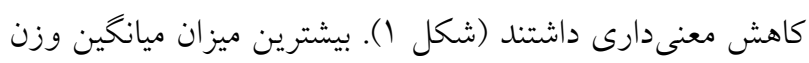

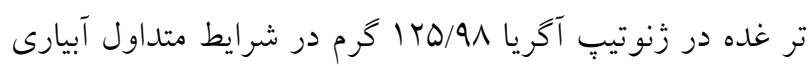

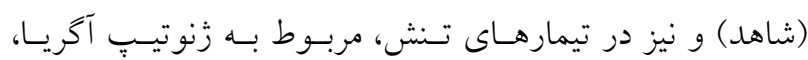

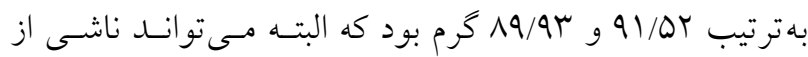

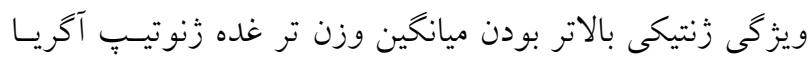

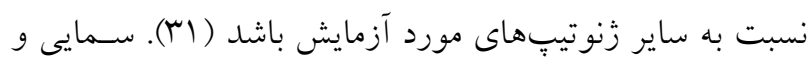

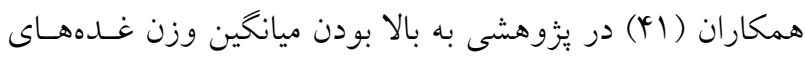

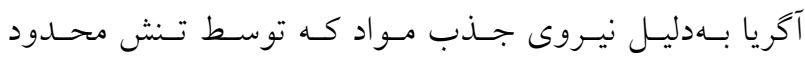

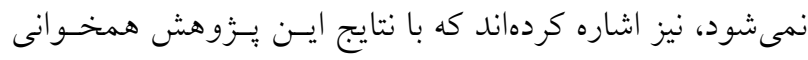

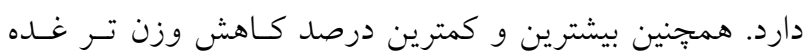

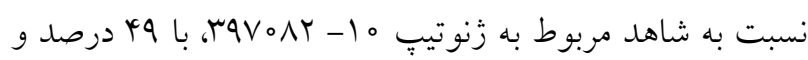

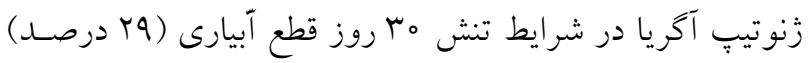

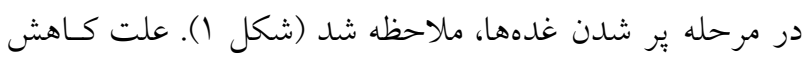

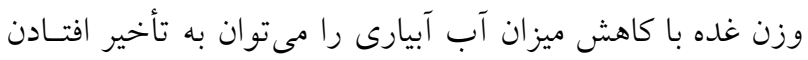

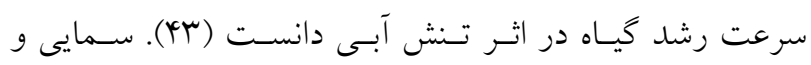

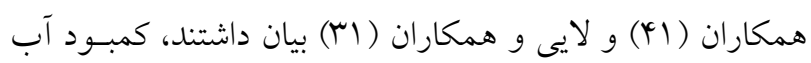
در طول دوره حجيم شدن غدهها تا حد زيـادى باعـث كـاهش ونش

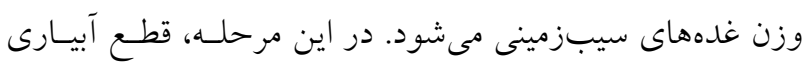

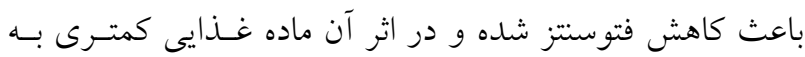

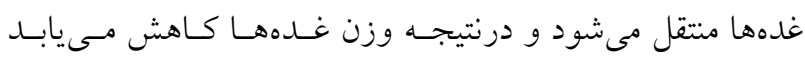

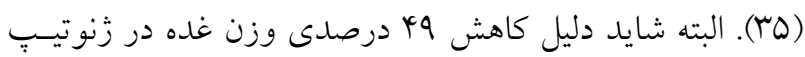

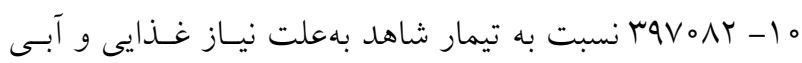
بالاتر اين زُنوتيب باشد كه بهدليل وقوع تــش غـذايى، افـزايش

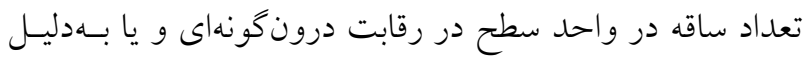
غلده زيادى كه در تراكم بالاى ساقه توليد مىشـود، ايجـاد شــهـ 


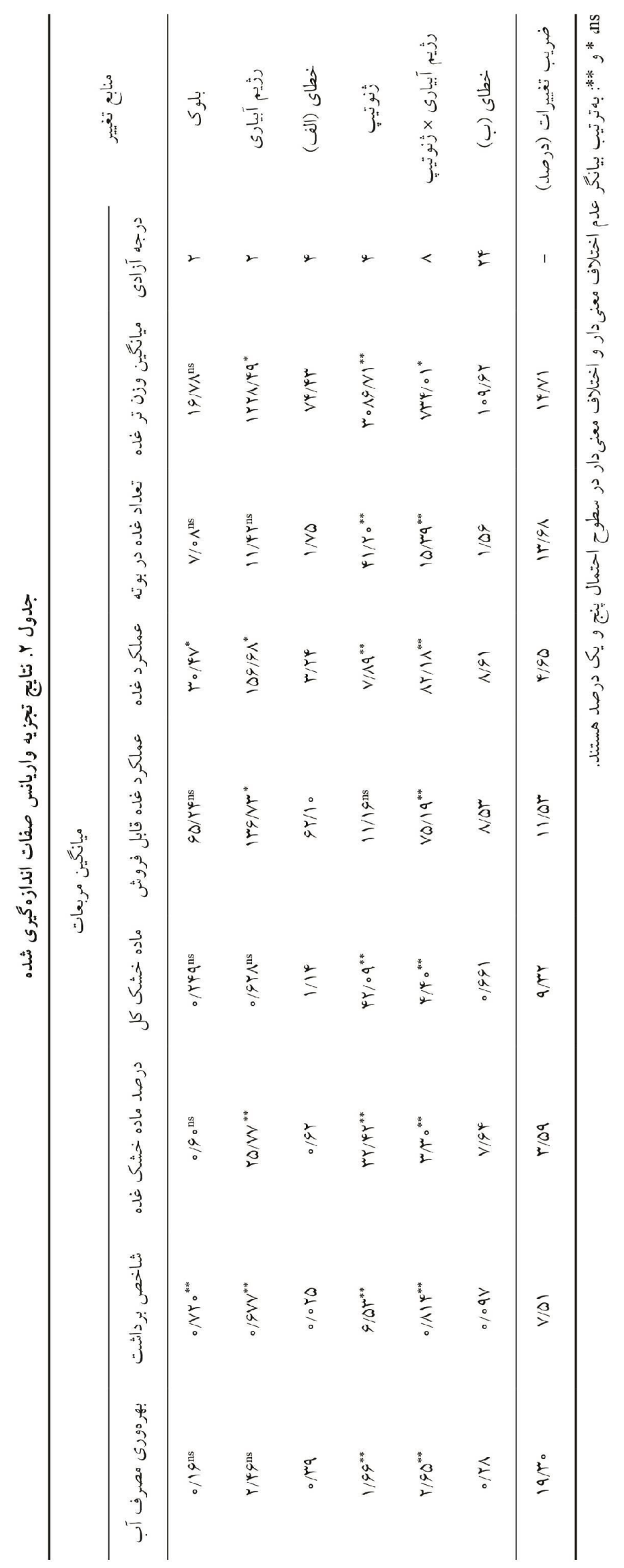




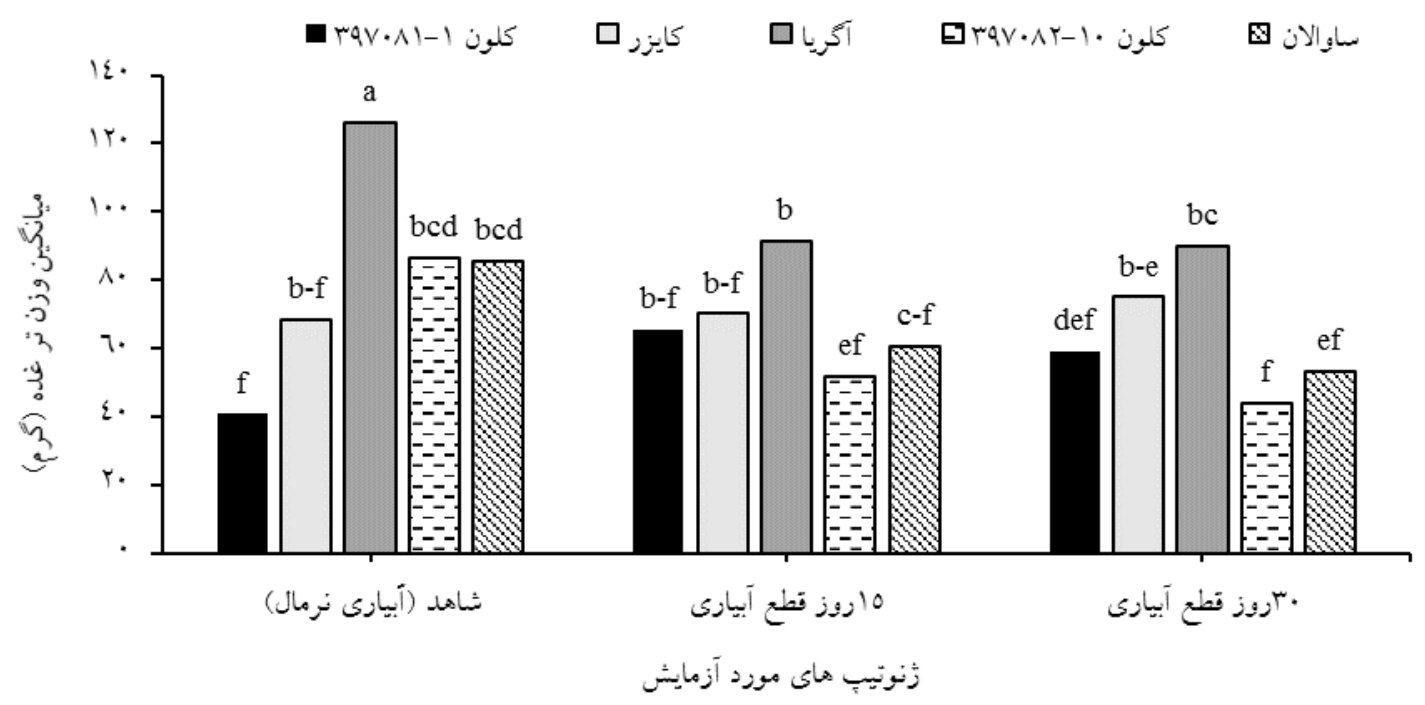

شكل ا. برهم كنث رنوتيٍّ در رزيم كم آبيارى بر ميانگين وزن تر غده (گرم). ميانخينهاى داراى حداقل يك حرف مشتر بر اساس آزمون

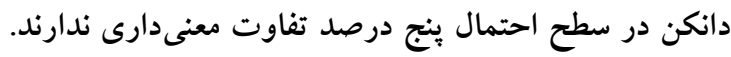

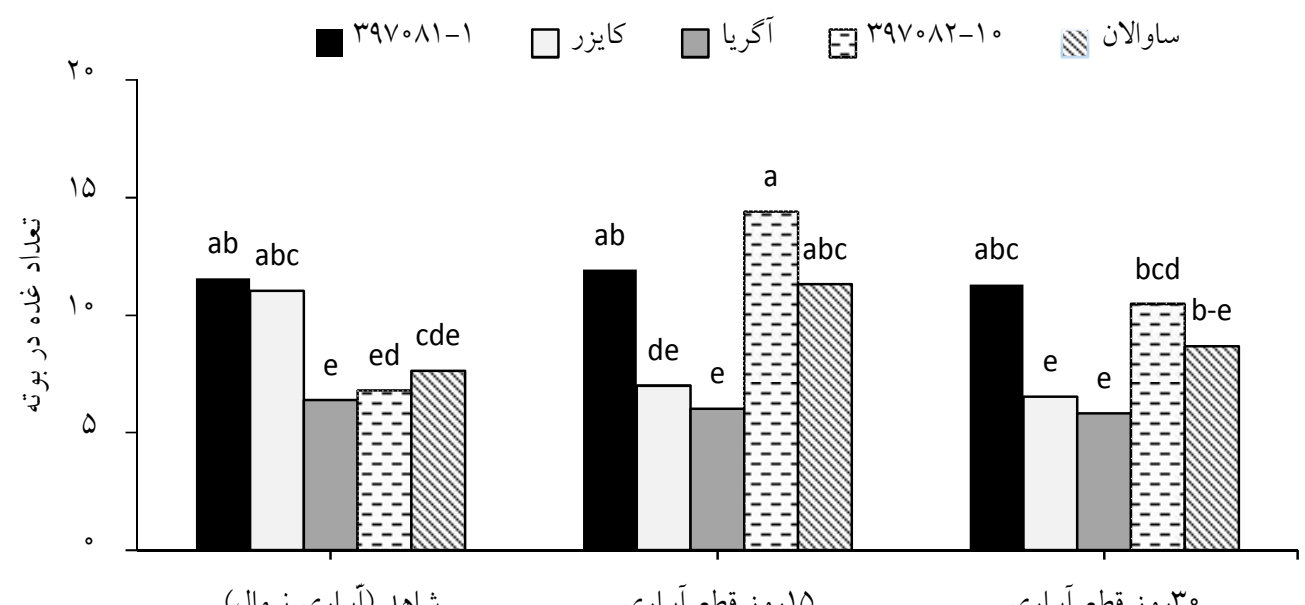

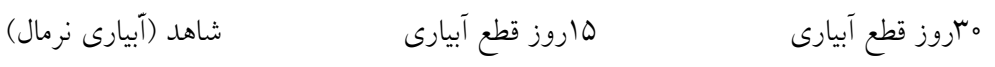

زنوتيبهاى مورد آزمايش

شكل r. برهم كنش زنوتيبٍ در رزيم كم آبيارى بر تعداد غده در بوته. ميانخينهاى داراى حداقل يكى حرف مشترك بر اساس آزمون دانكن در سطح احتمال يُنج درصد تفاوت معنى دارى ندارند.

نسبت به تيمار شاهد نشان داد (شـكل Y). سـمايى و همكـاران

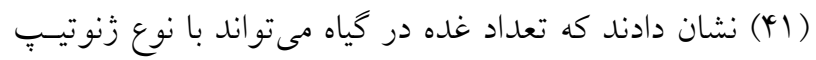
مرتبط باشد. شرايط محيطى مانند دما و نوع خاك نيز روى تعـداد

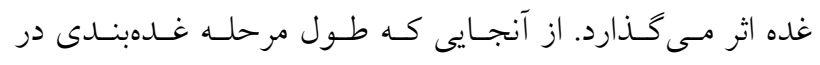

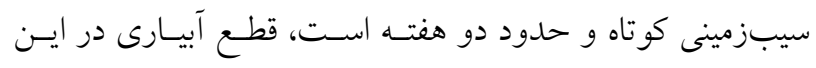

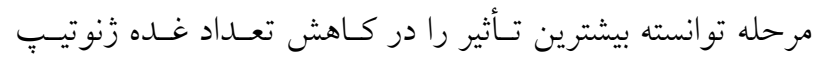

دارد. دومين مرحله رشد سيبزمينى مرحله تشكيل غــههاسـت

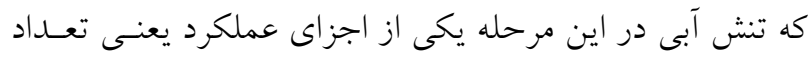
غده در بوته را كاهش مىدهد (Yr). اسكندرى و همكاران (IN)

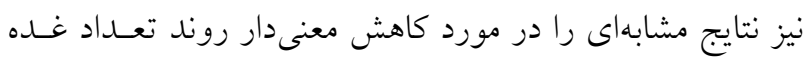
در بوته همراه با كاهش حجم آبيارى بهكار رفته كزارش كردند.

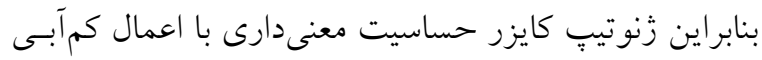




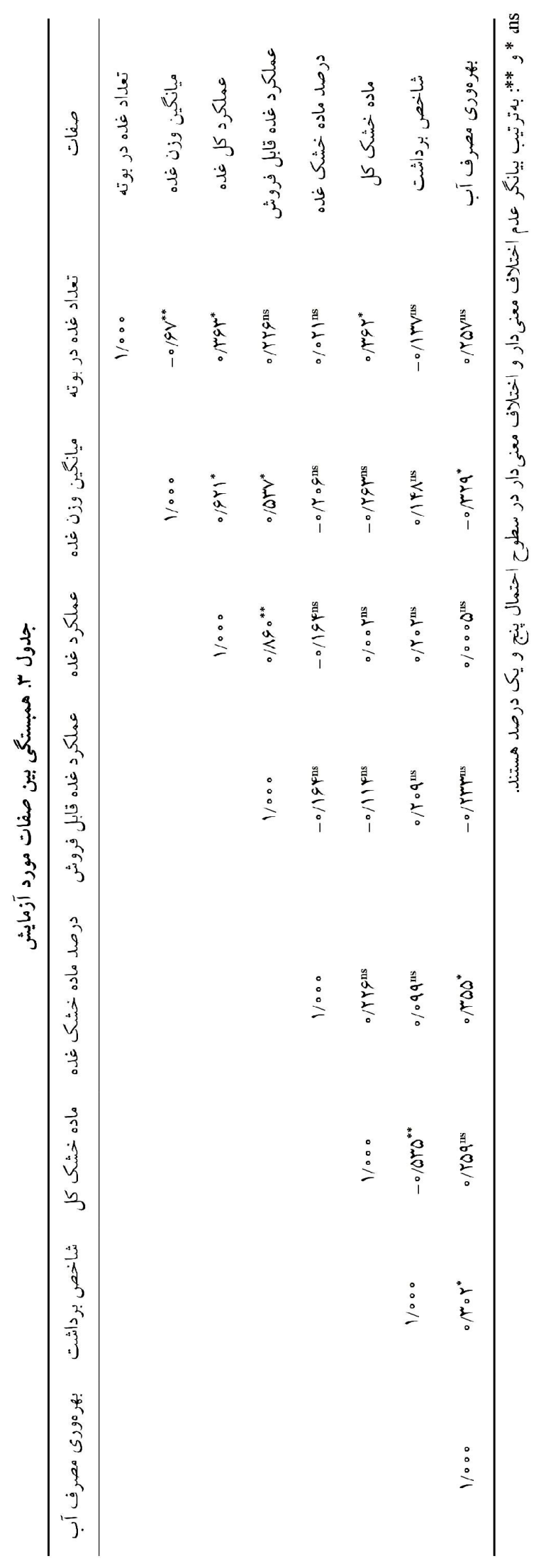


انتظار مىرود كه تغييرات در اجـزاى عملكـــد (تعـداد غــده در

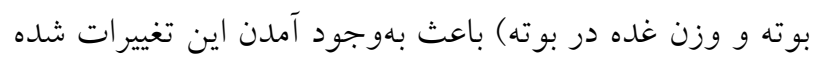

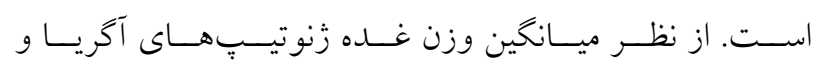
。

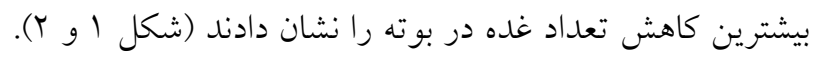

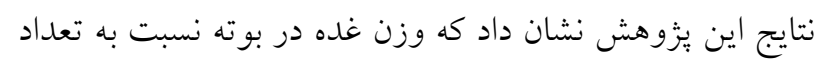

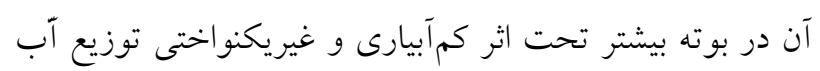

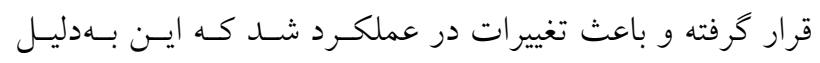

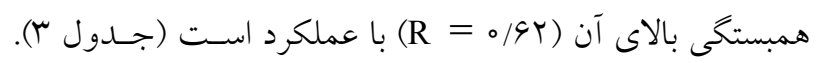
جون وقوع تنش باعث كاهش فتوسنتز و توسعه رويشى در كياه

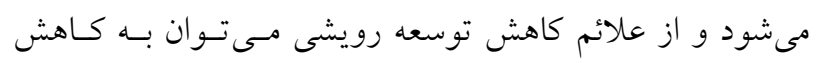

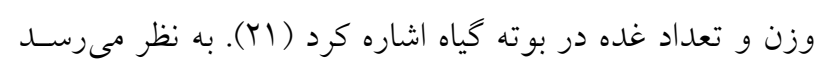

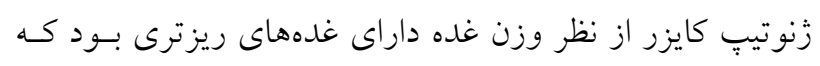

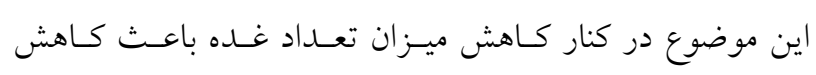

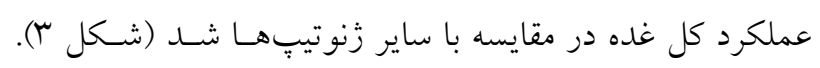

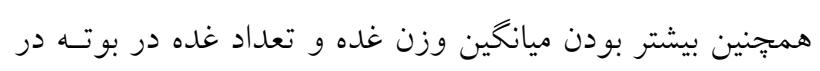

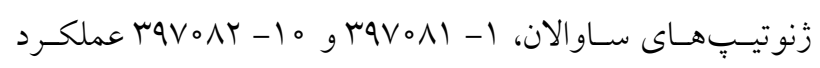

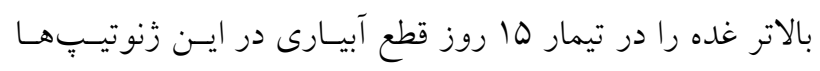

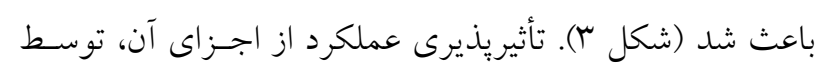

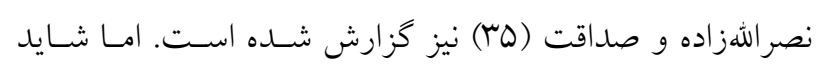

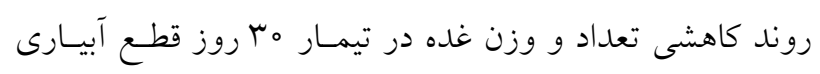

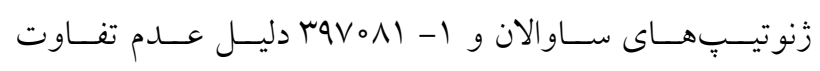

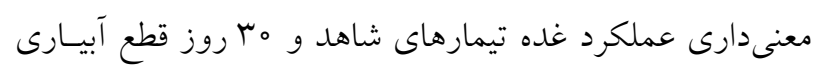

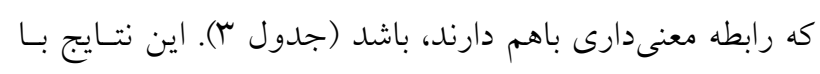

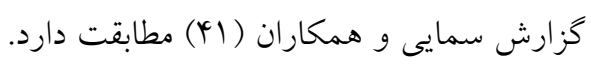

\section{عملكرد زيستى (ماده خشك كل)}

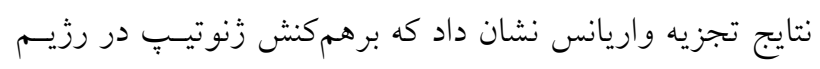
آبيارى براى صفت عملكرد ماده خشك كـل در سـطح احتمـال

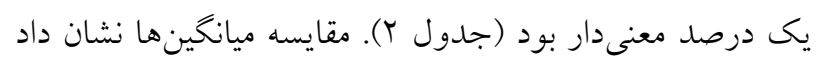

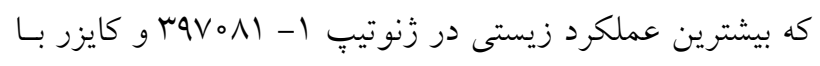
كاهش مقدار آب مصرفى بهدست آمد، بـهـطـورى كـه در تيمـار

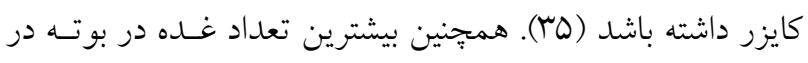

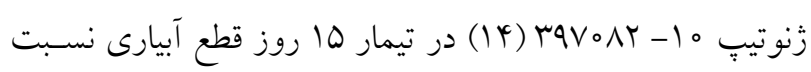

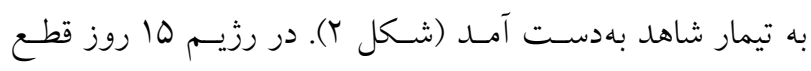

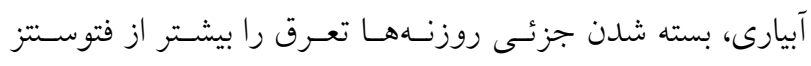

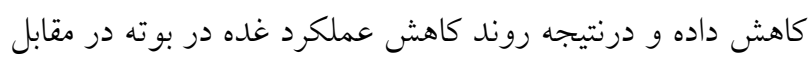

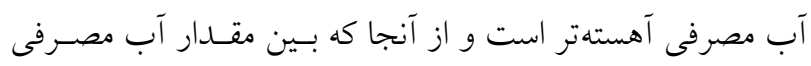

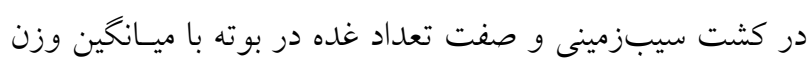

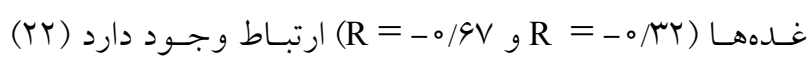

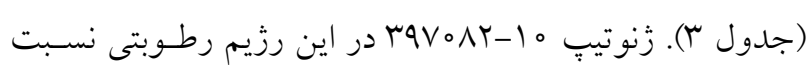

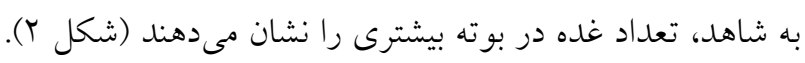

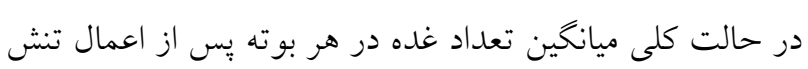
و ريكاورى كاهش يافت يا همسان حالت شاهد شـــ امـا نكتــهـ

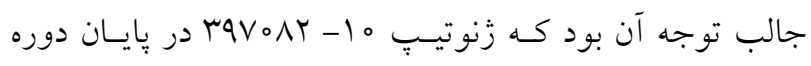

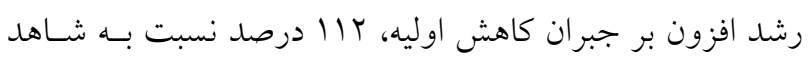

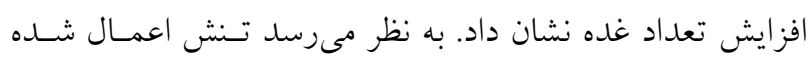

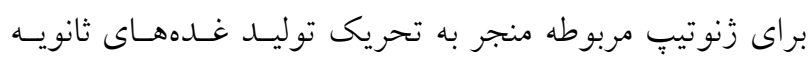

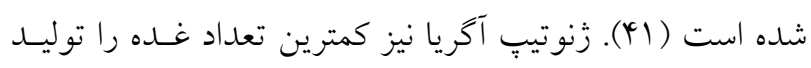

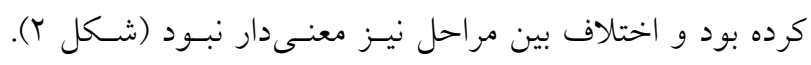

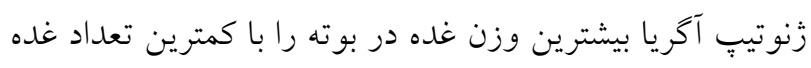

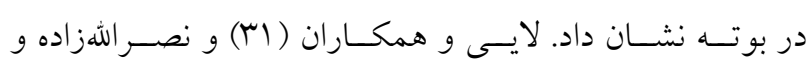

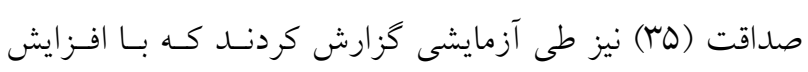

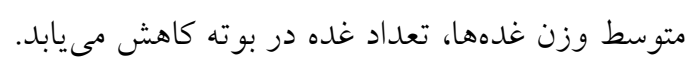

\section{عملكرد غده در واحد سطح}

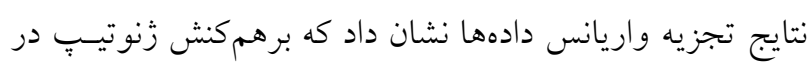

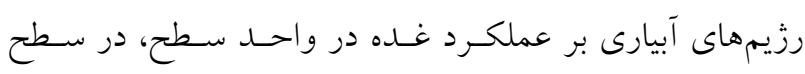

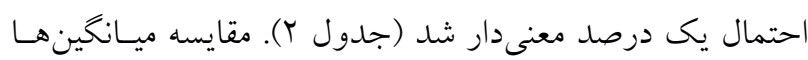

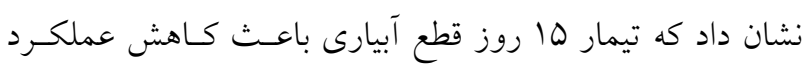

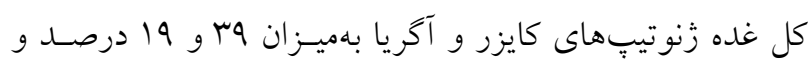

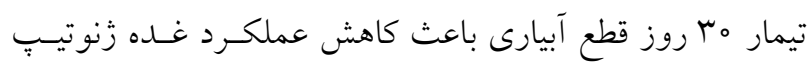

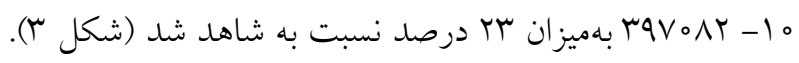

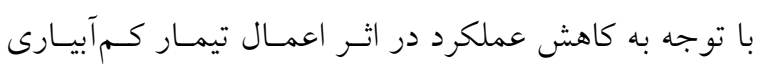




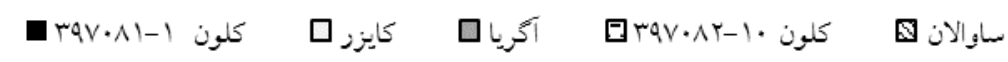

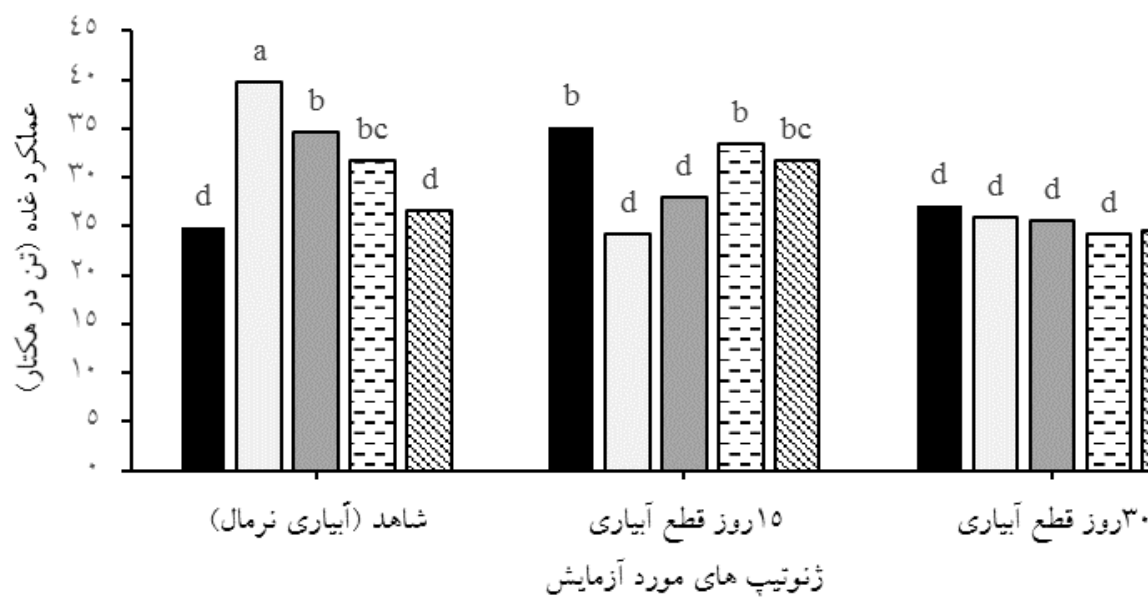

شكل r. برهم كنش زنوتيب در رزيم آبيارى بر عملكرد غده در واحد سطح (تن در هكتار)

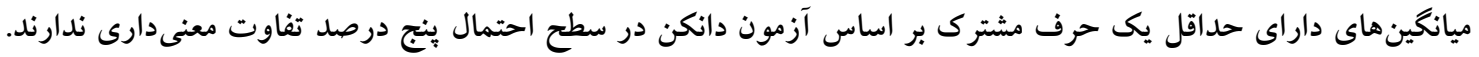

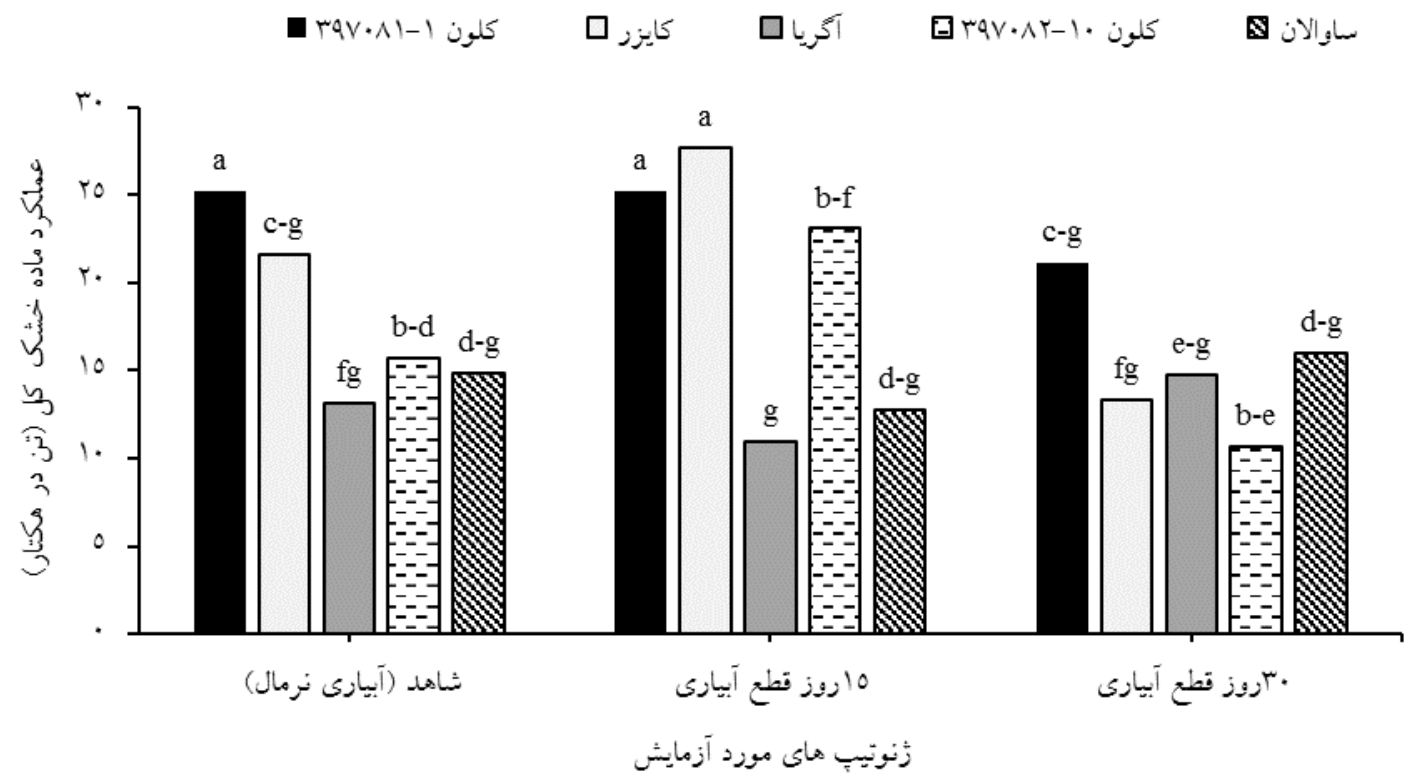

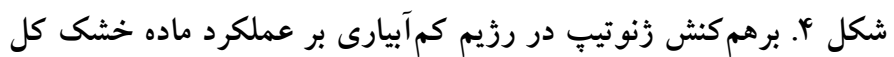

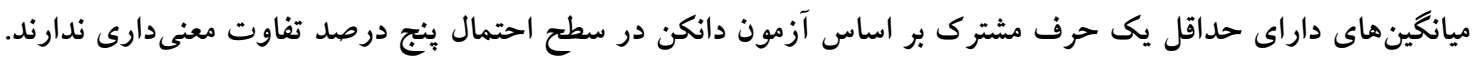

زنوتيبهـاى مـورد آزمـايش در شـرايط ها روز قطع آبيـارى و

همجنين جذب نيتروزن موجود در خـاك و سـبز بـاقى مانسدن و

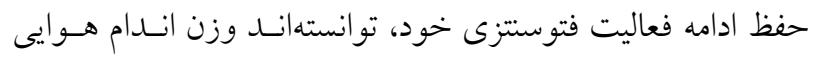

بيشترى داشته باشند (1). بيشترين درصد كاهش عملكرد زيستى

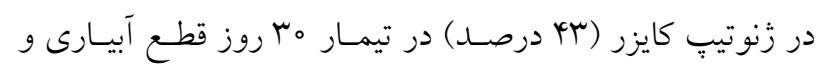

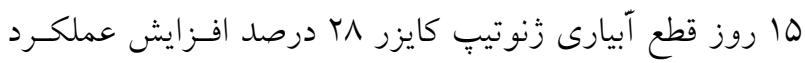

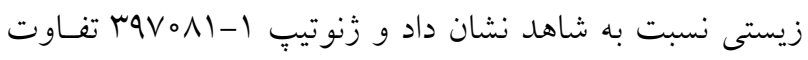

معنى دارى با تيمار شاهد نداشت (شكل ب).

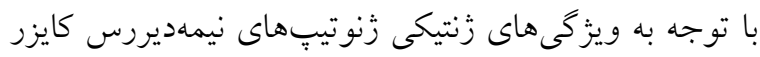

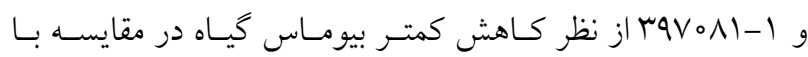




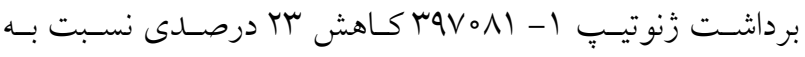

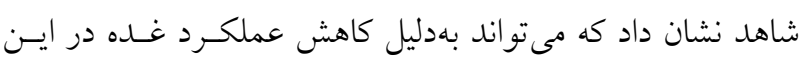

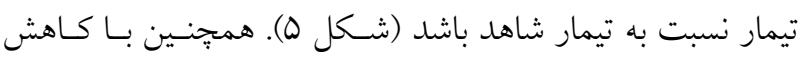

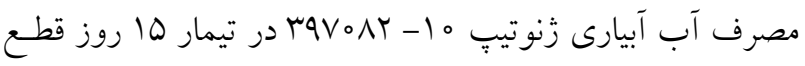
آبيارى VV درصد افزايش شاخص برداشت نسبت به شاهد نشـان

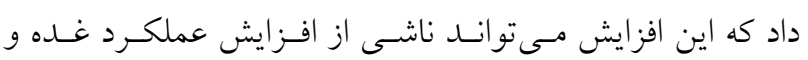
كاهش عملكرد زيستى اين زنوتيِ در اين تيمار نسبت بـه تيمـار

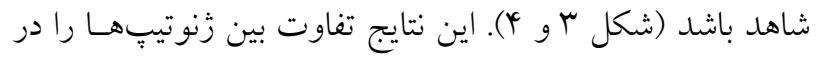
ميزان انتقال مواد فتوسنتزى توليدى اندامها به سمت غدهها نشـان مىدهد (N). با افزايش تنش رطوبتى، مقادير عملكرد غلده بـهــور مستقيم متأثر از كاهش در اجزاى تشكيل دهنده آن است و كـاهش شاخص برداشت گواه اين نكته اسـت كـه عملكـــد غـده در اثـر اعمال تنش آبى بر گياه، تأثيريذيرى بيشـترى نسـبت بـه عملكـرد ماده خشك (كل) كياه داشت و در ازاى اعمال تنش آبى، عملكرد غله به نسبت بيشترى در مقايسه با عملكـرد مـاده خشـى انـدام هوايى كياه كاهش يافت كه دليل عمده آن طولانى تر بـودن طـول دوره غدهبندى و بالاتر بودن سرعت انتقال مواد فتوسنتى اندامها به سمت غلده در تيمارهاى رطوبتى بـا فواصـل آبيـارى كمتـر در مقايسه با تيمارهاى تنش رطوبتى بود (I I ).

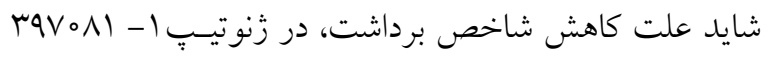

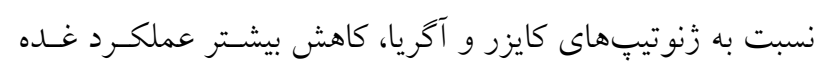

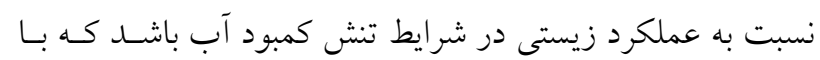
نتايج يزوهش ديخرى در اين مورد، همخوانى دارد (IV).

\section{عملكرد غده قابل فروش}

نتايج تجزيه واريانس مشخص كـرد كـهـ بــرهمكـش زنوتيــب در

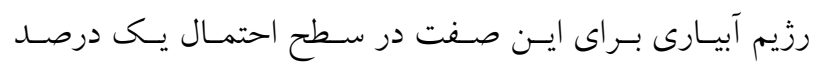
معنى دار بود (جدول Y). زنوتيـٍِهـاى كـايزر و آخريـا بيشـترين

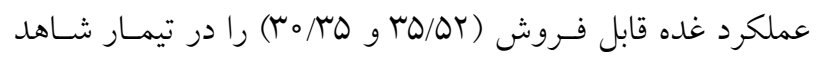
نشان داد كه تفاوت معنى دارى از نظر اين صفت بـين آنهـا ديــده نشد. ولى با كاهش مصرف آب عملكرد غده قابل فروش زنوتيتٍ كايزر (19/1 آتـن در هكتـار) در تيمـار ها روز قطـع آبيـارى و

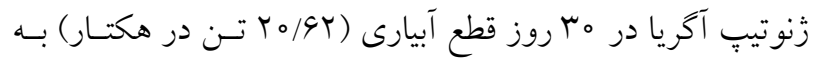

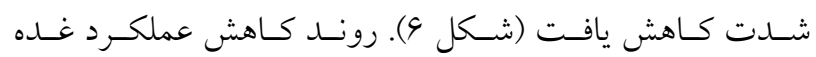

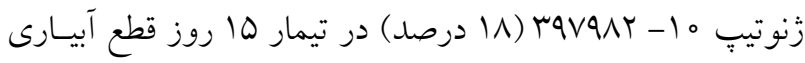
بهدست آمد، هر جند كه از لحاظ آمارى تفاوت معنى دارى با تيمار

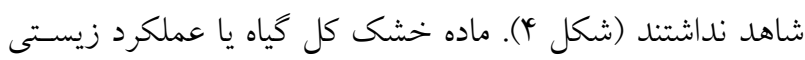
نتيجه مو اد فتوسنتزى است. ماده خشك اندامها بـا كذشــت زمـان كاهش مى يابد و علت آن انتقال مو اد فتوسـتنزى بـه غــدهاسـت

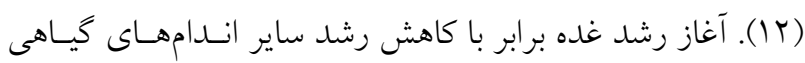
است. اختلافهاى زيادى كه در عملكرد كل مـاده خشـى ديـده مىشود، علاوهبر اينكه درنتيجه اختلاف در سرعت فتوسـتنز آنها است، مىتواند بهعلت تفاوت در مدت زمانى كه فتوستتز در آنهـا ادامه دارد نيز باشد (سץ). عملكرد زيستى در كليـه زنوتيـٍِهـا در شرايط تنش نسبت به شاهد مربوطه كاهش يافت. بـهــورى كـه كزارش شده اسـت سـيبزمينسى قـرار گرفتـه در معسرض تـنش

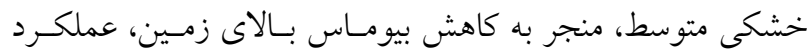

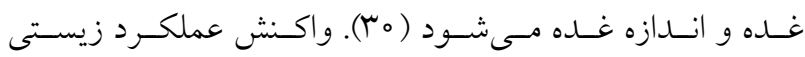
زَنوتيِهاى آخريا و ساوالان نيز از لحاظ آمارى با كاهش مصرف آب آبيارى نسبت به تيمار شاهد معنى دار نبود. بـا اينكــه زنوتيـبِ

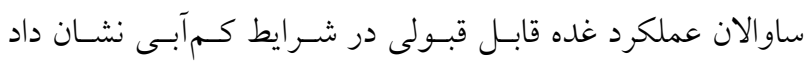

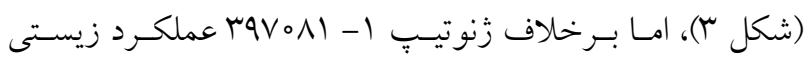
خوبى نداشت كه بهنظر مىرسـد كـاهش عملكـرد ايسن زنوتيـيٍ بيشتر به خاطر تعلداد كمتر غلده توليدى نسبت بـهـ تـاـــــم تـداوم

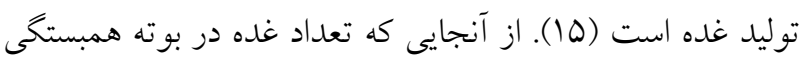

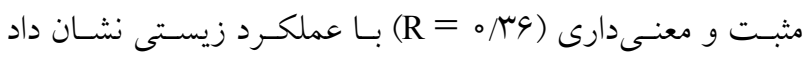
(جدول ץ)، بنابر اين كاهش تعداد غده در بوته مسىتوانـد بـهــور مؤثرى عملكرد را كاهش دهد (هr).

\section{شاخص برداشت}

نتايج تجزيه واريانس نشان داد كه بــهمكـنش زنوتيـبِ در رزيسم آبيـارى روى شـاخص برداشـت در سـطح احتمـال يـك درصــ

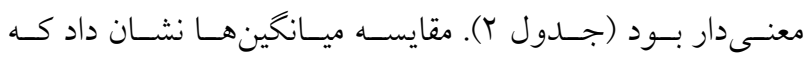
زنوتيبٍ

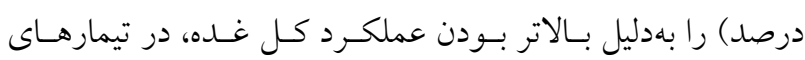
آزمايشى نشان دادند (شكل ه). كه البته تفاوت معنى دارى از نظـر

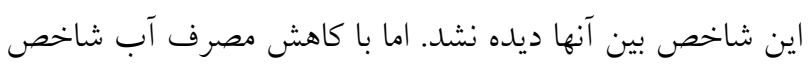




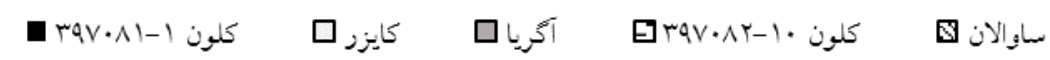

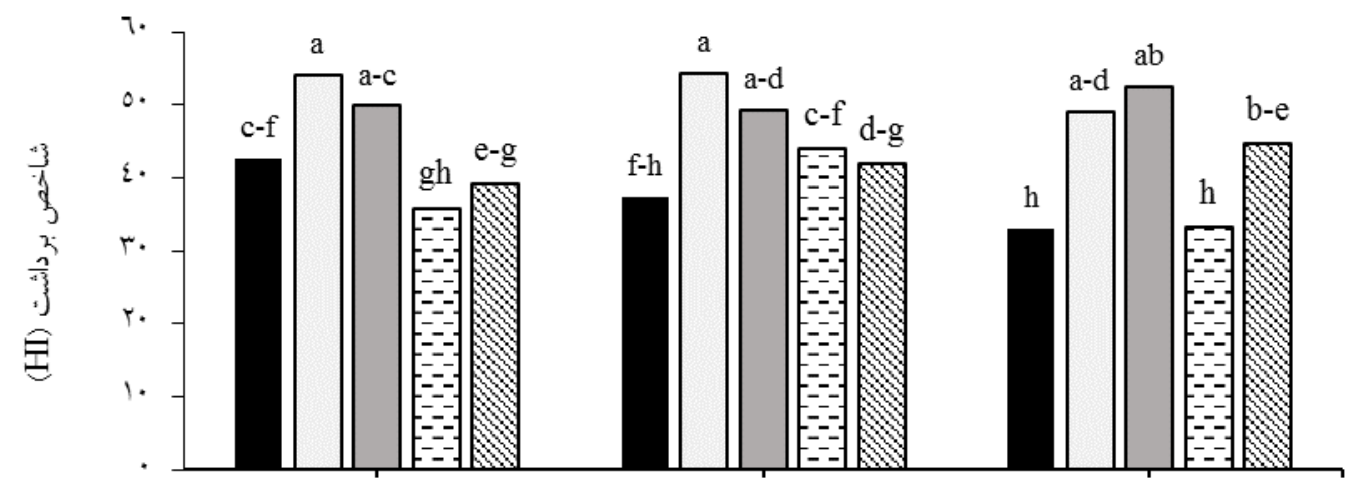

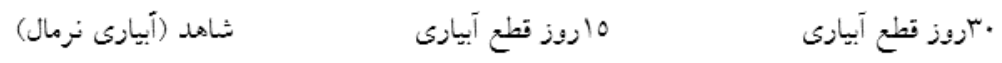

زَنويتبِ هاى موزد آزمايث

شكل ه. برهم كنش زُنوتيّ در رزيم كممآبيارى بر شاخص برداشت

ميانگينهاى دار اى حداقل يك حرف مشترى بر اساس آزمون دانكن در سطح احتمال ينج درصد تفاوت معنىدارى ندارند.

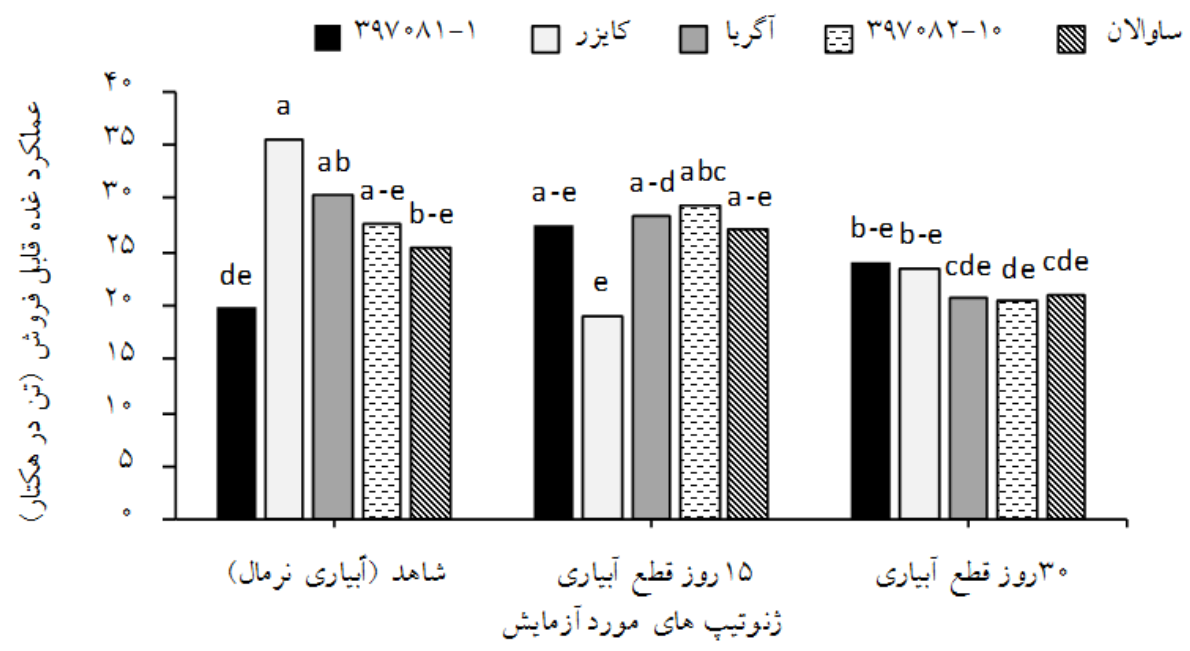

شكل 9. برهم كنش زنوتيب در رزيم كمآبيارى بر عملكرد غده قابل فروش

ميانگينهاى داراى حداقل يك حرف مشترى بر اساس آزمون دانكن در سطح احتمال ينج درصد تفاوت معنىدارى ندارند.

اثر كم آبيـارى و غيريكنـواختى توزيـع آب قــرار كرفتـهـ و باعـث

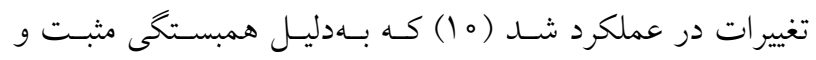

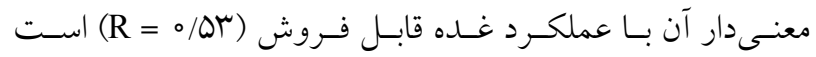

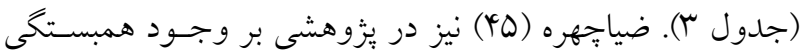

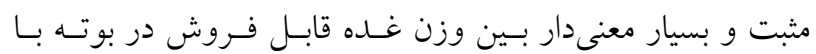

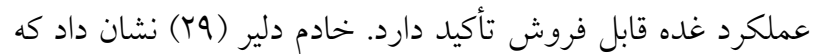

قابل فروش با روند كـاهش آب مصـرفى يكسـان و تـا حـدودى مشابه اثر آبيارى بر عملكرد كل غده بود (N) (1). با توجه به كـاهش عملكرد در اثر اعمال كمآبيـارى انتظـار مسىرود كـهـ تغييـرات در اجزاى عملكرد (تعداد غلده در بوته و وزن غــده در بوتـه) باعـث بهوجود آمدن اين تغييرات شده است. نتايج ايسن يـروهش نشـان داد كه وزن غلده در بوته نسبت به تعداد آن در بوته بيشـتر تحـت 
زنوتيبها كه حساسيت كمترى در اين مرحله با حفظ عملكــد

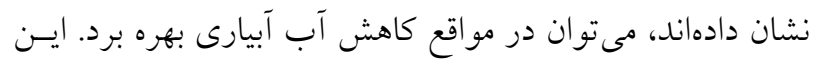

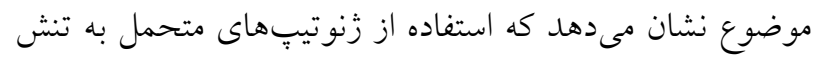

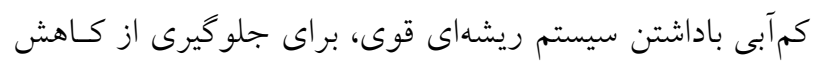
عملكرد غلده مؤثر است (10).

\section{درصد ماده خشك غده}

نتايج تجزيه واريانس مشخص كرد كه بـرهمكـش زنوتيـٍ در

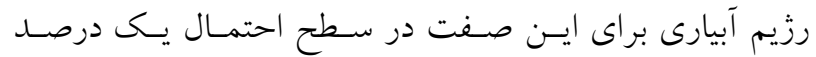

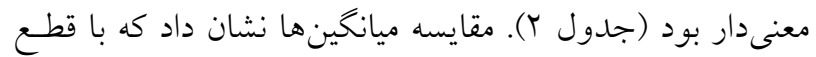
آبيارى بيشترين درصد ماده خشك غده در زنوتيبهاى كايزر و

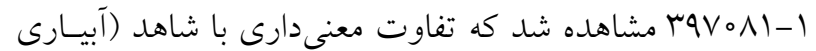

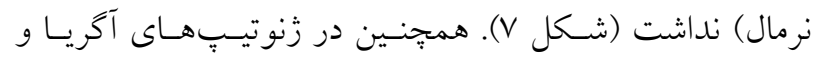

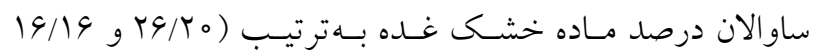
درصد) در تيمار ها روز قطع آبيارى نسبت بـه شـاهد افـزايش

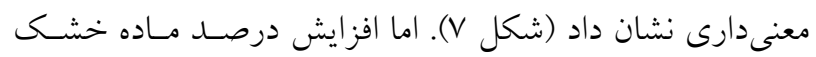

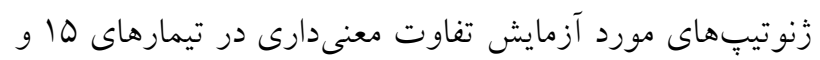
مبر روز قطع آبيارى با يكديخر نشان ندادند.

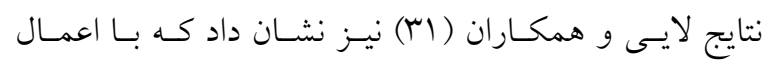

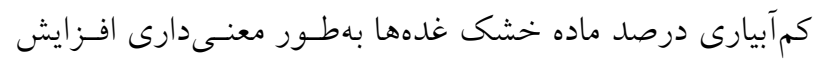

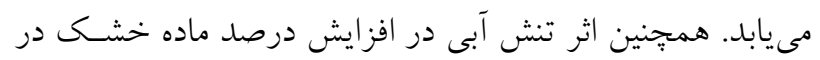

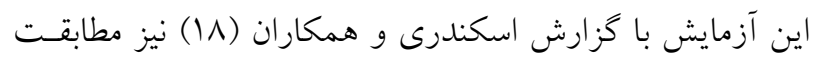

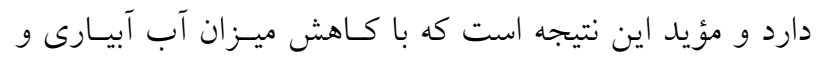
اعمال تنش خشكى درصد ماده خشك غدهها افزايش يافته و در

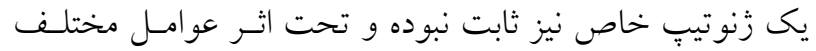

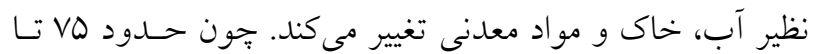

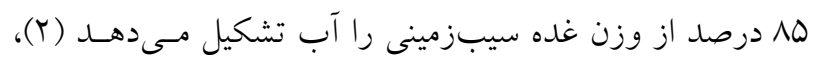
بنابراين مىتوان هنين بيان كرد كه افزايش اين صفت با افزايش

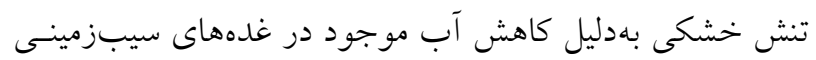

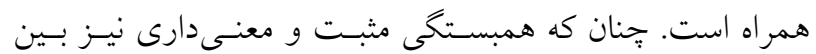
درصد ماده خشك غده و بهرهورى مصرف آب (سماهله

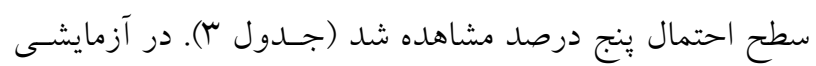

تنش كمآبى بيشترين خسارت را به عملكرد غده قابـل فـروش از

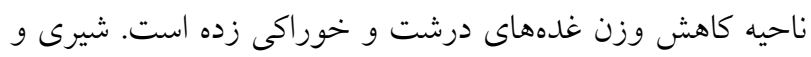

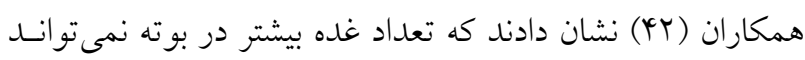

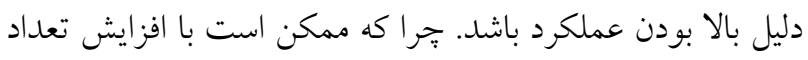
غده رقابت بين غدهها براى دريافت مـواد يـرورده بيشـتر شـده و درنتيجه اندازه غدها كوجكى مىماند. اما در تيمارهايى كه درصـد بالايى غدههاى درشت دارند، مىتوان دليل افزايش قطر غدههـا را كاهش تعداد غدهها دانست كه به اين ترتيب در افزايش عملكـرد غلده قابل فروش نقش خو اهند داشت (Yo). تنش آبى موجـب توقـف تشـكيل غــده همســان و تشكيل

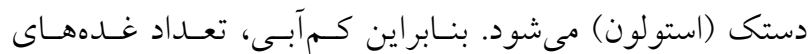

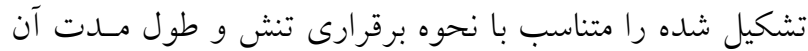
كاهش مىدهل و هنخامى كه آبيارى يـس از اعمـال تــش اجـرا

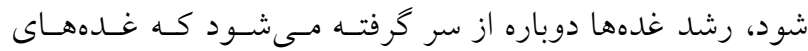

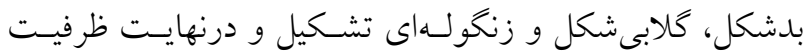
عملكرد غده قابـل فـروش كيـاه را كـاهش مسيدهـــ (م 1). در حقيقت مىتوان بيان كرد وزن تر غدهها و اندازه آنها تعيين كننده

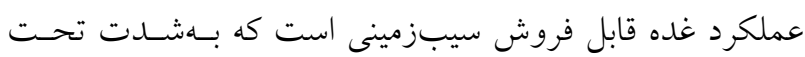

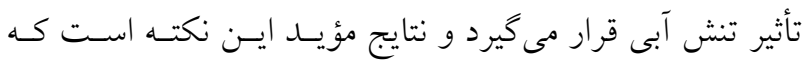

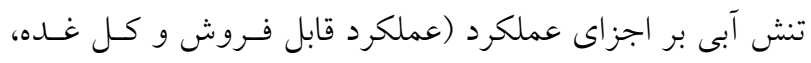

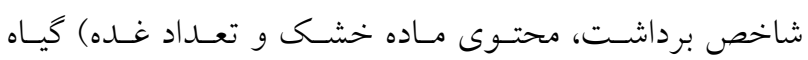

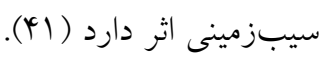

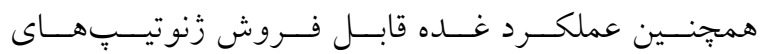
1-

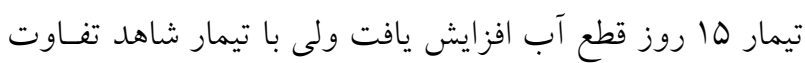
معنىدارى نداشـتند (شـكل 9). در ايسن ي-هزوهش زمـان اعمـال

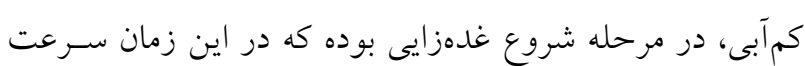
رشد اندام هوايى گياه كندتر است و انتظـار مسىرود در شـر ايط تنش، مواد غذايى ساخته شده در برى گياه بهميزان بيشترى بـهـ

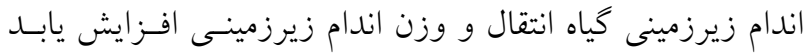

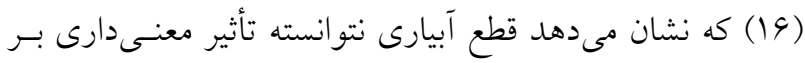

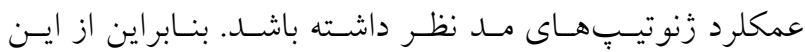


صاوالان

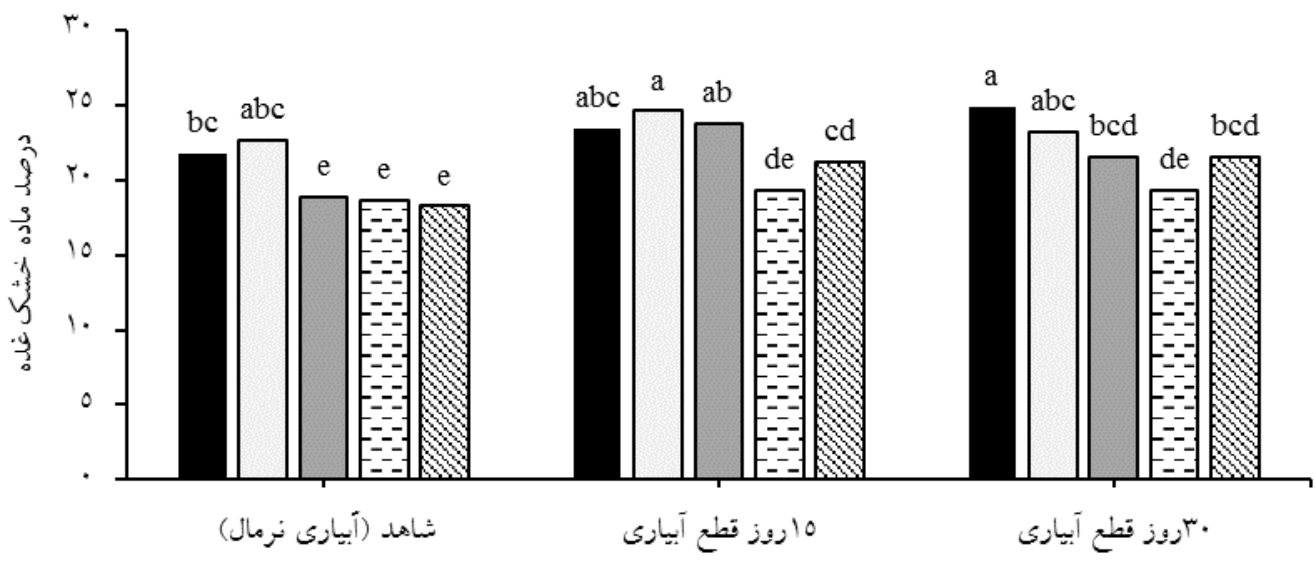

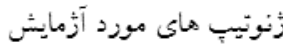

شكل V. برهم كنش زنوتيب در رزيم كم آبيارى بر عملكرد بر درصد ماده خشك غده

ميانگينهاى داراى حداقل يك حرف مشترك بر اساس آزمون دانكن در سطح احتمال بنج درصد تفاوت معنىدارى ندارند.

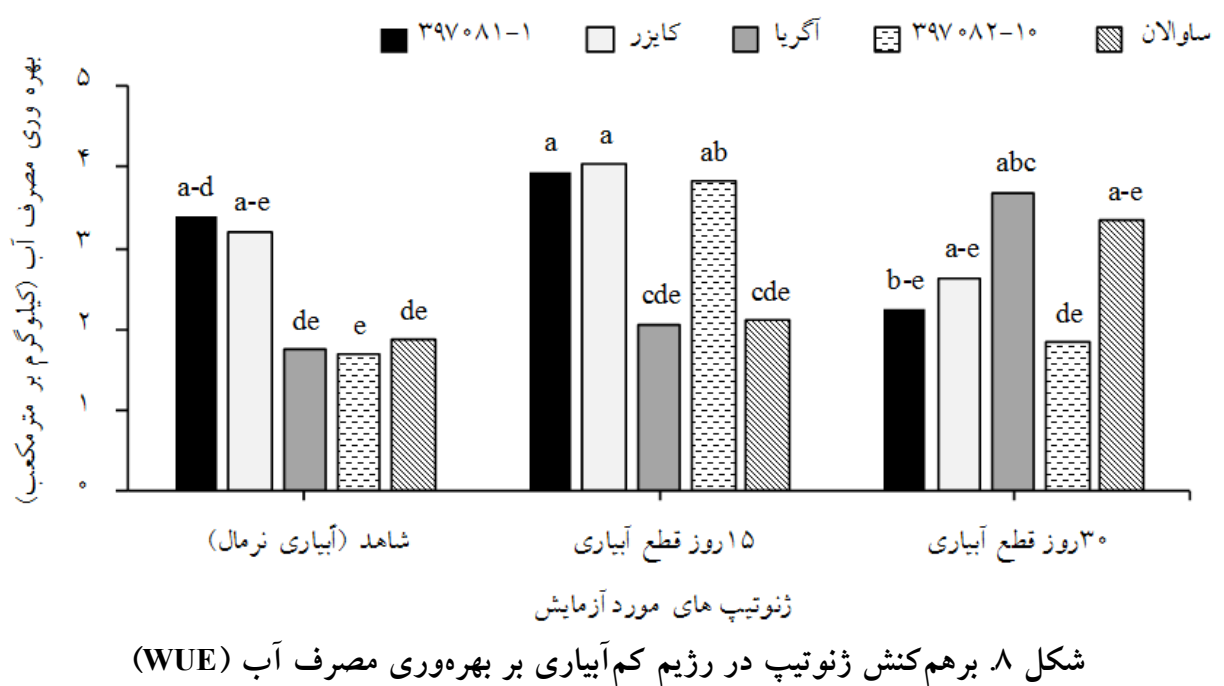

ميانگينهاى داراى حداقل يك حرف مشترك بر اساس آزمون دانكن در سطح احتمال ينج درصد تفاوت معنىدارى ندارند.

معنى دار بود (جدول Y). نتايج مقايسه ميانكينهـا نشـان داد كـه

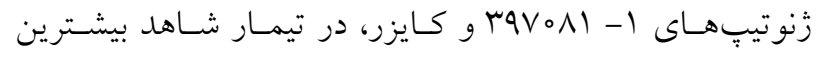

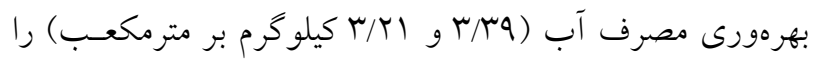
نشان دادند كه با كاهش مصـرف آب آبيـارى در تيمـار ها روز قطع آبيارى، اين مقدار افزايش يافت ولى با تيمار شاهد از نظـر آمارى تفاوت معنى دارى نداشت (شكل ^).
بيان شده است محتواى ماده خشك غدههاى سيبزمينى با افـزايش تنش خشكى افزايش مىيابد و كمترين ماده خشك در تيمار شـاهد و بيشترين آن مربوط به تيمار با تنش خشكى شديد بود (11). بهرهورى مصرف آب (WUE) (كيلو گرم بر مترمكعب) نتايج تجزيه واريانس مشخص كرد كه بـرهمكـش زنوتيـيّ در رزيم آبيارى براى ايسن صـفت در سـطح احتمـال يـك درصـد 


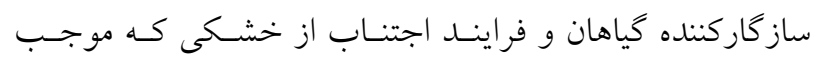

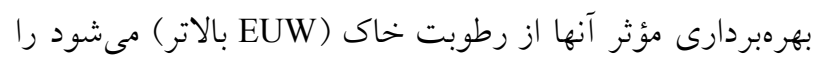

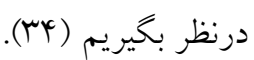

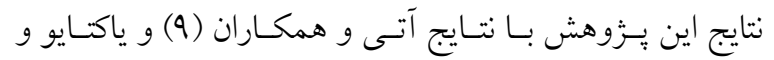

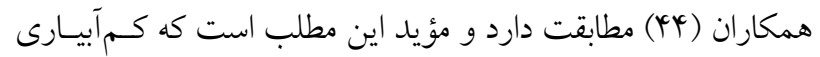

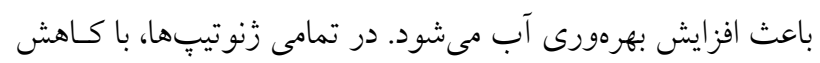

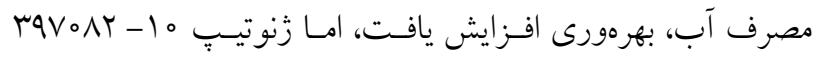

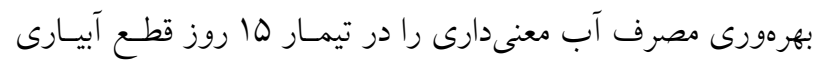

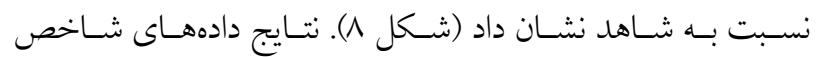

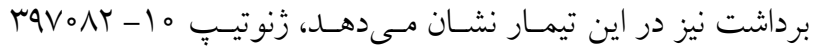

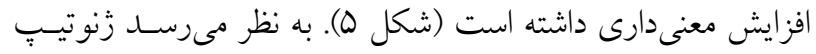

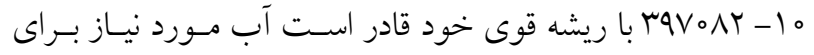

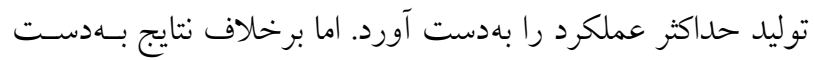

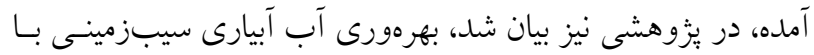

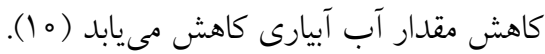

\section{نتيجه گيرى}

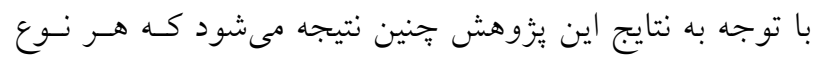

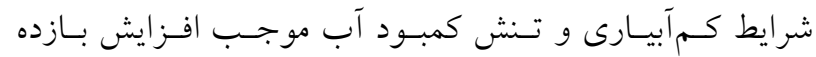

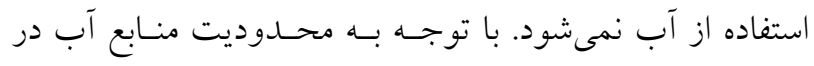
مناطق خشك و نيمهخشـ و از طرفى نيـاز آبسى بـالاى گيساه

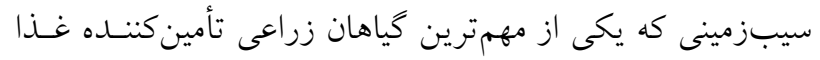

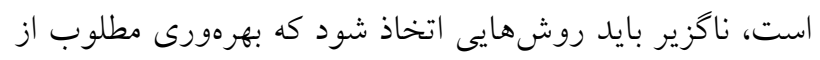

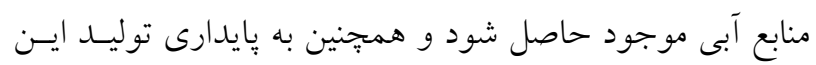

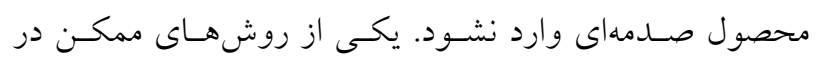

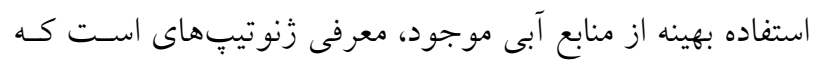

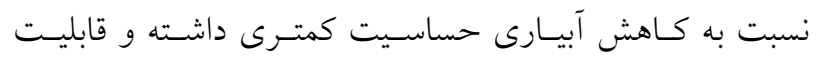

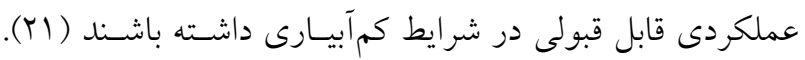

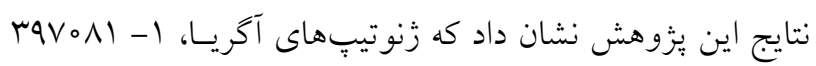

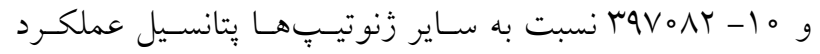

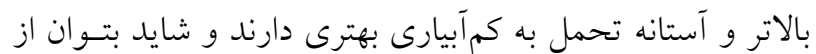

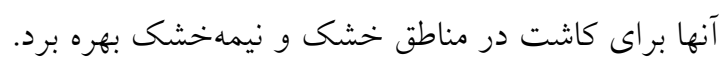

نتايج همبستكى بـين مـاده خشك و بهـرهورى مصـرف آب زنوتيـٍ

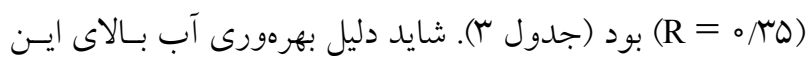

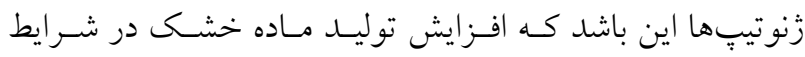

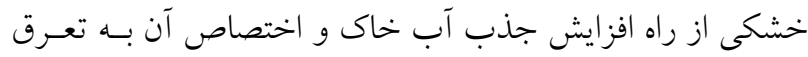

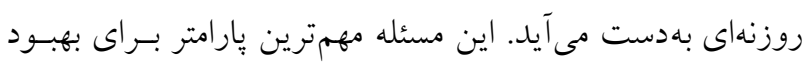

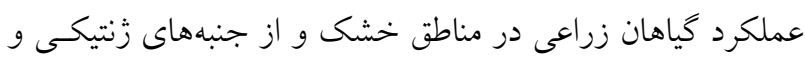

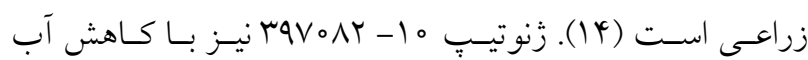

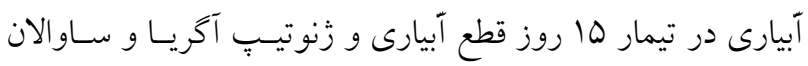

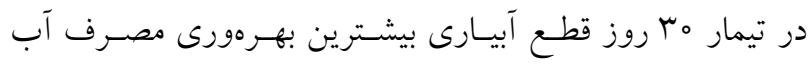

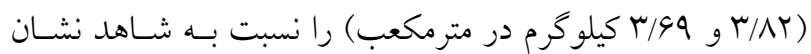
دادند، اما زنوتيبٍ ساو الان بـا شـاهد تفـاوت معنسى دارى نداشـت

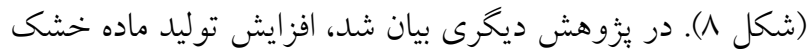

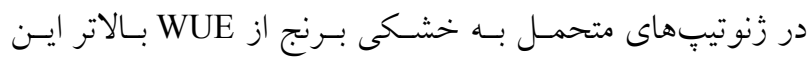

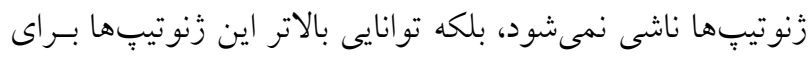

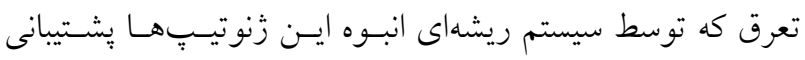

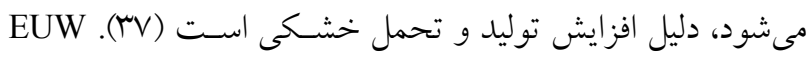

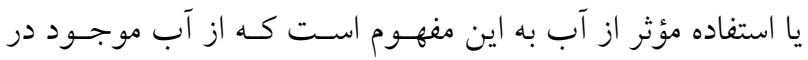

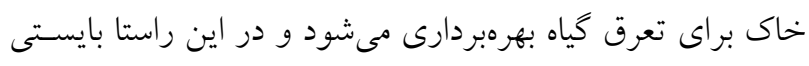

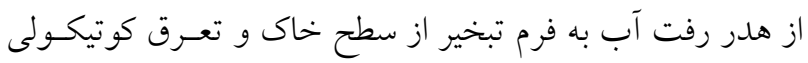

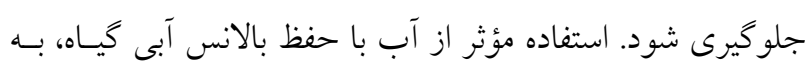

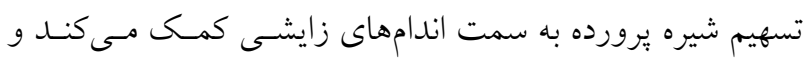

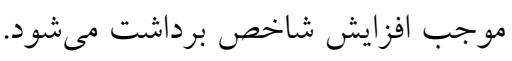

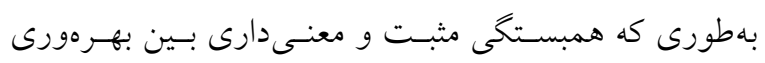

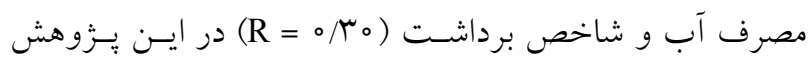

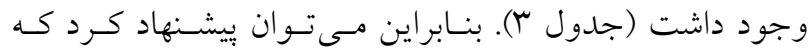
EUW مى تواند جايكزين WUE بهعنوان صـفت مـورد استفاده

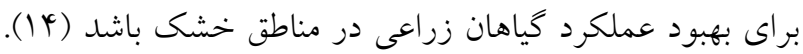

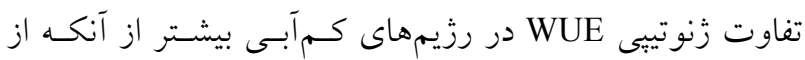
تفاوت در توليد ماده خشك ناشى شود از تفاوت در استفاده از

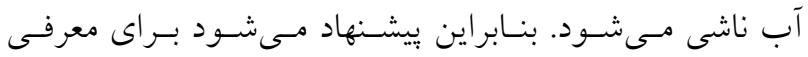
زنوتيبٍاى متحمل به خشكى بايستى ويزگى هاى سـاختمانى و 
1. Agharezaei, M., S. H. Ahmadi, A. A. Kamkar Haghighi, A. R. Sepaskhah and J. Javanmardi. 2014. The effect of low irrigation and irrigation part of the roots on the physiological characteristics of three potato cultivars. In: Proceeding of the Second National Conference on Water Management at the Field. Soil and Water Research Institute. Iran. 39- 44. (In Farsi).

2. Agili, S., B. Nyende, K. Ngamau and P. Masinde. 2013. In vitro evaluation of orange-fleshed sweet potato for drought tolerance using polyethylene glycol. In: Proceeding of the $9^{\text {th }}$ Triennial African Potato Association Conference Naivasha, Kenya.

3. Ahmadi Adli, R. 2006. Determination of water irrigation and water consumption in potato cultivation in Ardabil. Journal of Sustainable Agricultural Science 16: 235- 244. (In Farsi).

4. Ahmadi, K., H. Gholizadeh, H. Ebadzadeh, F. Hatami, M. Fazli, A. Kazemiyan and M. Rafiei. 2016. Agriculture agricultural cultivar. 2014-2014 Volume I: Crop products. Tehran, Ministry of Agricultural Jihad, Deputy Director of Planning and Economics, ICT Center. (In Farsi).

5. Allen, R. G., L. S. Pereira, D. Raes and M. Smith. 1998. Crop Evapotranspiration Guidelines for computing crop water requirements. FAO Irrigation and Drainage Paper, No. 56, Rome, Itally.

6. Allen, R. G. and W. O. Pruitt. 1991. FAO- 24. Reference evapotranspiration factors. Journal of Irrigation and Drainage England ASCE 117, 758-773.

7. Al-Mahmud, A., Md. A. Hossain, Md. A. Al-Mamun, Md. Sh. Ebna Habib, Md. Sh. Rahaman, Md. Sh. Ali Khan, and Md. M. Bazzaz. 2014. 2014. Plant canopy, tuber yield and growth analysis of potato under moderate and severe drought condition. Journal Plant Science 2(5): 201-208.Alva, A. K., H. Ren and A. D. Moore. 2012. Water and nitrogen management effects on biomass accumulation and partitioning in two potato cultivars. American Journal of Plant Sciences 3: 164-170.

8. Ati, A., A. Iyada and S. Najim. 2012. Water use efficiency of potato (Solanum tuberosum L.) under different irrigation methods and potassium fertilizer rates. Annals of Agricultural Science 57(2): 99-103.

9. Ayas, S. 2013. The effects of different regimes on potato (Solanum tuberosum L. Hermes) yield and quality characteristics under unheated greenhouse conditions. Bulgarian Journal of Agricultural Science 19: 87-95.

10. Baciu, A. 2013. Reaction of native potato varieties to water stress. Potato Research and Development Station-Targu Secuiesc, Romania Journal of Horticulture, Forestry and Biotechnology 17(2): 80- 86.

11. Badarau, C. L., A. Marculescu and N. Chiru. 2013. The effects of new treatments on PVY infected potato plants under drought conditions. Bulletin of the Transilvania University of Braşov Series II: Forestry \& Wood Industry \& Agricultural Food Engineering 655: 99-104.

12. Bagherniae Kasbakhi, M. and D. Hassanpanah. 2014. Evaluation of yield and tuber yield components in the hybrids produced from crosses of Agria and Ceaser potato cultivars. In: Proceeding of the $1^{\text {st }}$ E- Conferences on New Finding in Environment and Agricultural Ecosystems. University of Tehran, Iran. (In Farsi).

13. Blum, A. 2009. Effective use of water (EUW) and not water-use efficiency (WUE) is the target of crop yield improvement under drought stress. Field Crops Research 112: 119-123.

14. Cabello, R., F. De Mendiburu, M. Bonierbale, P. Monneveux, W. Roca and E. Chujoy. 2012. Large scale evaluation of potato improved varieties, genetic stocks and landraces for drought tolerance. American Journal of Potato Research 895: 400-410.

15. Demelash, N. 2013. Deficit irrigation scheduling for potato production in North Gondar, Ethiopia. African Journal of Agricultural Research 8(11): 1144-1154.

16. Ebrahimipak, N. A. 2014. Determination of the potato yield response factor (Ky) to deficit irrigation in different growth stages in sharekord. Journal of Irrigation and Water Engineering 15: 39- 50. (In Farsi).

17. Eskandari, A., H. R. Khazaie, A. Nezami and M. Kafi. 2011. Study the effects of irrigation regimes on yield and some qualitative characteristics of three cultivars of potato (Solanum tuberosum L.). Journal of Water and Soil 25(2): 240- 247. (In Farsi).

18. FAO. 2014. FAOSTAT database for agriculture. Available online at: http://faostat3.fao.org/ faostat gateway/go/to/download/Q/QC/E.

19. Ghobady, M., S. Jahanbin, K. Parvizi and R. Motalebifard. 2011. Effect of phosphorus bio fertilizers on yield and yield components of potato. Journal of Agricultural Science and Sustainable Production 21(2): 118-130.

20. Haghighi, B., S. Broomandnasab and A. A. Naseri. 2015. Effect of irrigation water on performance, some quality characteristics and water productivity of two potato cultivars. Quarterly Journal of Plant Growth Physiology, Islamic Azad University 7(28): 60-45. (In Farsi).

21. Hassanpanah, D. 2010. Evaluation of potato cultivars for resistance against water deficit stress under in vivo conditions. Potato Research 5: 383-392. 
22. Hassanpanah, D. and H. Hassanabadi. 2011. Evaluation of quantitative and qualitative characteristics of promising potato clones in Ardabil region. Agroecology Journal 7(22): 37-48. (In Farsi).

23. Hassanpanah, D. and H. Hassanabadi. 2012. Evaluation of quantitative, qualitative and tuber yield stability of 18 promising potato clones in Ardabil province. Journal of Crop Ecophysiology 6(2): 219-234. (In Farsi).

24. Hassanpanah, D., SH. Honardoost. 2010. Compared of Yield Promising Clones 397082-2, 397097-2 and 397081-1 with Area Control (Agria cultivar). Agriculture Natural Resources Research Center of Ardebil. (In Farsi).

25. Hassanpanah, D., A. A. Hoseinzadeh. 2007. Methodology and Evaluation of Resistance Sources to Drought in Potato Cultivars and Path Analysis of Yield and Yield Components. Project Final Report, Ardabil Agricultural and Natural Resources Research Center. (In Farsi).

26. Hoekstra, A. Y. 2002. Virtual water trade: Proceedings of the international expert meeting on virtual water trade, Delft, The Netherlands, 12-13 December 2002. UNESCO-IHE, Delft, The Netherlands. Value of Water Research Report Series. 2003; No. 12.

27. Kazemi, M., H. Hassan Abadi and H. Tavakoli. 2011. Potato Production Management. Training and Promoting Agriculture Press. Tehran, Iran. (In Farsi).

28. Khademdalir, M. 2003. Study of new potato cultivars under limited irrigation conditions in Ardabil. MSc. Thesis, Faculty of Agriculture and Natural Resources. University of Zabol. Iran. (In Farsi).

29. Kumari, S. 2012. Influence of drip irrigation and mulch on leaf area maximization, water use efficiency and yield of potato (Solanum tuberosum L.). Journal of Agricultural Science 4(1): 71-80.

30. Laei, G., M. Noryan and H. Afshari. 2012. Determination of the planting depth of potato seed tuber yield and yield components of two varieties agria and draga response curves seed. Annals of Biological Research 12: 5521-5528.

31. Mohammadi, A., H. Yosefi, Y. Noorallahi and S. J. SadatineJad. 2017. Choose the best province in potato production by assessing water footprint index. Journal of Ecohydrology 4(2): 523- 532. (In Farsi).

32. Molaei, B., M. Gheysari, B. Mostafazadeh Fard, E. Landi and M. M. Majidi. 2015. Evaluation of yield and yield characteristics of two potato varieties under sprinkler and trickle irrigation systems. Quarterly Water and Soil Science (Journal of Science and Technology of Agriculture and Natural Resources) 19(71): 241-250. (In Farsi).

33. Naderi, M., M. Shayannejad, S. Heydari and B. Haghighati. 2016. Effect of different levels of irrigation water on quantitative and qualitative characteristics of potato and determination of its optimum consumptive use of water in Shahrekord. Journal of Water and Soil 30(5): 1371- 1380. (In Farsi).

34. Nasrollahzadeh Asl, A. and Gh. Sedaghat. 2017. Effects of planting depth and irrigation disruption on yield and yield components in potato (Solanum tuberosum L.). Journal of Crop Science Research in Arid Regions 1(1): 109119. (In Farsi).

35. Nouri1, A., A. Nezami, M. Kafi and D. Hassanpanah. 2016. Evaluation of water deficit tolerance of 10 potato cultivars based on some physiological traits and (Solanum tuberosum L.) tuber yield in ardabil region. Journal of Crop Ecophysiology 10(1): 243- 268. (In Farsi).

36. Palta, J. A., X. Chen, S. P. Milroy, G. J. Rebetzke, M. F. Dreccer and M. Watt. 2011. Large root systems: are they useful in adapting wheat to dry environments? Functional Plant Biology 38: 347-354.

37. Postini, K., A. Siyosemardeh, M. Zavareh and Sh. Madah Hosseyni. 2005. Crop yields - physiology and processes. Tehran University Press. Tehran. (In Farsi).

38. Raesi Asad Abadi, M., M. R. Nouri Emamzadei and R. Fatahi. 2017. Improving irrigation schedule of potato in order to improve water use efficiency index. Irrigation Sciences and Engineering 40(2): 199- 207. (In Farsi).

39. Rasoolzadeh, A. and M. Raoof. 2014. Principles and Methods of Irrigation. Amidi Publications, Tabriz, Iran. (In Farsi).

40. Samaee, M., S. A. M. Modarres-Sanavy, A. Mousapour Gorji and E. Zand. 2017. The study of potato genotypes (Solanum tubersum L.) tolerance to water deficit stress. Iranian Journal of Field Crop Science 47(4): 527-540. (In Farsi).

41. Shiri Janagard, M., A. Tobeh, R. Asghari Zakaria, G. Nouri- Ganbalani and B. Dehdar. 2007. The effects of different levels of drip irrigation and cultivation pattern on yield and yield components of the agria potato. Pajouhesh \& Sazandegi 75: 149- 157. (In Farsi).

42. Sobhani, A. and H. Hamidi. 2014. Evaluation of yield and growth indices of potato under different levels of water deficit stress. Iranian Journal of Field Crops Research 12: 283-295. (In Farsi).

43. Yactayo, W., D. A. Ramírez, R. Gutiérrez, V. Mares, A. Posadas and R. Quiroz. 2013. Effect of partial root-zone drying irrigation timing on potato tuber yield and water use efficiency. Agricultural Water Management 123: 65-70.

44. Ziyachehreh, M. 2017. Investigating the reaction of a number of potato superior cultivars and clones at different levels of irrigation and limited to phenological factors of morphology and various quantitative and qualitative characteristics of crops. MSc. Thesis. Faculty of Agriculture and Natural Resources, University of Mohaghegh Ardabili. Ardabil. Iran. (In Farsi). 


\title{
Effect of Different Irrigation Regimes on Physiological Characteristics, Yield and Water Productivity of Potato Genotypes in Ardabil
}

\author{
A. Shafaroodi ${ }^{1}$, A. Gholipouri ${ }^{*}$, M. Zavareh ${ }^{3}$, D. Hassanpanah ${ }^{4}$ and B. Salahi ${ }^{5}$
}

(Received: June 27-2018; Accepted: December 26-2018)

\begin{abstract}
In order to detect the reaction of different potato genotypes to different irrigation regimes and evaluate their water productivity, a research was carried out as a split plot experiment based on a randomized complete block design with three replications in Agricultural Research Center and Natural Resources of Ardabil, Iran in 2015-2016. Five potato genotypes (Agria, Caesar, Savalan, 397081-1 and 397082-10) and three irrigation regimes (normal irrigation, 15 and 30 days without irrigation after 75 days of normal irrigation) were considered as treatments. The results showed that the effect of irrigation cuttings on the genotypes was significant for the mean fresh weight of tuber, number of tubers per plant, tuber yield per unit area, total dry matter yield and harvest index, marketable yield, dry matter percentage of tuber and water use efficiency. Under water stress conditions, water use efficiency was increased on the basis of tuber yield per unit area and marketable yield in genotypes 397081-1, Agria and 397082-10. The highest water use efficiency was observed based on harvest index in Caesar and Agria genotypes (54.29 and 49.29 percent, respectively), and also based on the percentage of dry matter of tubers in genotypes 397081- 1, Caesar and Agria (6, 9 and 26 percent, respectively). When producing the highest tuber yield and water use efficiency under drought stress is aimed at planting genotypes 1-397081, agria and 397082-10 may bring about an effective use of water and show better growth and yield.
\end{abstract}

Keywords: Dry matter yield, Effective use of water (EUW), Harvest index, Low irrigation, tuber yield

1, 2. PhD. Student and Associate Professor, Respectively, Department of Agronomy and Plant Breeding, Faculty of Agriculture, Mohaghegh Ardabili University, Ardabil, Iran.

3 Associate Professor, Department of Agronomy and Plant Breeding, Faculty of Agriculture, Guilan University, Rasht, Iran.

4. Assistant Professor, Horticulture Crops Research Department, Ardabil Agricultural and Natural Resources Research Centre, AREEO, Ardabil, Iran.

5. Professor, Department of Geography, Faculty of Geography, Mohaghegh Ardabili University, Ardabil, Iran.

*: Corresponding Author, Email: gholipouri@uma.ac.ir 